\title{
Sill to surface: Linking young off-axis volcanism with subsurface melt at the overlapping spreading center at $9^{\circ} 03^{\prime} \mathrm{N}$ East Pacific Rise
}

\author{
Christopher L. Waters ${ }^{a, b, *}$, Kenneth W.W. Sims ${ }^{\text {a,b }}$, Emily M. Klein ${ }^{c}$, Scott M. White ${ }^{\text {, }}$, \\ Mark K. Reagan ${ }^{\mathrm{e}}$, Guillaume Girard ${ }^{\mathrm{e}}$ \\ a Department of Geology and Geophysics, University of Wyoming, Laramie, WY 82072, USA \\ ${ }^{\mathrm{b}}$ Department of Geology and Geophysics, Woods Hole Oceanographic Institution, Woods Hole, MA 02543, USA \\ ${ }^{\mathrm{c}}$ Division of Earth and Ocean Sciences, Nicholas School of the Environment, Duke University, Durham, NC 27708, USA \\ ${ }^{\mathrm{d}}$ Department of Earth and Ocean Sciences, University of South Carolina, Columbia, SC 29208, USA \\ e Department of Geoscience, University of Iowa, Iowa City, IA 52242, USA
}

\section{A R T I C L E I N F O}

\section{Article history:}

Received 10 April 2012

Received in revised form 26 February 2013

Accepted 5 March 2013

Editor: T. Elliott

Available online 20 April 2013

Keywords:

U-series

East Pacific Rise

mid-ocean ridge basalt

off-axis

submarine volcanism

\begin{abstract}
A B S T R A C T
No young, off-axis, mid-ocean ridge lavas have yet been directly linked to underlying off-axis melt bodies. In this study, we present new measurements of ${ }^{238} \mathrm{U}-{ }^{230} \mathrm{Th}-{ }^{226} \mathrm{Ra}-{ }^{210} \mathrm{~Pb}$ isotope compositions for a suite of lavas from the overlapping spreading center (OSC) at $9^{\circ} 03^{\prime} \mathrm{N}$ on the East Pacific Rise (EPR). These lavas span a large range of compositions, from basalt to dacite, and include both axial and off-axis samples recovered from a prominent, axis-parallel pillow ridge and a flat-topped seamount that overlie the westernmost extent of a 4-km-wide melt lens (Kent et al., 2000). We report ${ }^{210} \mathrm{~Pb}$ excesses in axial basalts and basaltic andesites, which we suggest results from gas-magma fractionation of ${ }^{222} \mathrm{Rn}$ from ${ }^{226} \mathrm{Ra}$ beneath dacite magmas. In addition, our U-series ages agree with visual observations, indicating that while most recent volcanic activity occurs at the spreading axis, active volcanism also occurs away from the axis. Specifically, the off-axis pillow ridge and seamount samples overlying the off-axis subsurface melt body have eruption ages of less than $8 \mathrm{ka}$, and likely as young as $1 \mathrm{ka}$, despite being located on crust that has a spreading age of $\sim 75 \mathrm{ka}$. The young ages of these lavas, combined with existing geological, geochemical and geophysical constraints, provide evidence for a genetic link between the pillow ridge and seamount lavas and the seismically imaged, underlying off-axis melt lens. This link demonstrates that off-axis volcanism does not necessarily come from a sub-axial magma body and can be sourced directly from off-axis magma bodies.
\end{abstract}

(c) 2013 Elsevier B.V. All rights reserved.

\section{Introduction}

The relationship between axial volcanism and the underlying axial magma chamber at fast-spreading mid-ocean ridges has long been established (e.g., Sinton and Detrick, 1992), but there has been no definitive evidence linking off-axis volcanism with off-axis magma bodies. Off-axis eruptions are known to occur along the East Pacific Rise (EPR), including large off-axis lava fields, small volcanic cones, and seamounts (Batiza and Vanko, 1984; Hall and Sinton, 1996; Geshi et al., 2007; White et al., 2002; Sims et al., 2003). However, the origin of these lavas with regards to their crustal magma source remains speculative largely because of the lack of (1) comprehensive seismic imaging of crust underlying off-axis lava fields and (2) absolute ages of off-axis lavas.

The overlapping spreading center (OSC) at $9^{\circ} 03^{\prime} \mathrm{N}$ EPR presents an ideal opportunity for studying the relationships between volcanism

\footnotetext{
* Correspondence to: University of California San Diego, Geosciences Research Division, Scripps Institution of Oceanography, 9500 Gilman Drive, La Jolla, CA 92093-0244, USA. Tel.: +1 8585344716.

E-mail address: clwaters@ucsd.edu (C.L. Waters).
}

and magmatism because the subsurface melt distribution and seafloor morphology have recently been well-characterized in a number of geophysical and geological studies (e.g., Bazin et al., 2003; Combier et al., 2008; Dunn et al., 2001; Kent et al., 2000; White et al., 2009). Using ${ }^{238} \mathrm{U}-{ }^{230} \mathrm{Th}-{ }^{226} \mathrm{Ra}-{ }^{210} \mathrm{~Pb}$ age dating, we identify young, axis-parallel volcanism ( $<8 \mathrm{ka}$ ) up to $\sim 4 \mathrm{~km}$ off-axis that directly overlies the western extent of a seismically imaged melt sill (Kent et al., 2000). The young ages for these off-axis lavas, combined with other geologic, petrologic, and geophysical constraints, provide, for the first time, substantive evidence for a genetic link between young off-axis volcanism and subsurface melt.

\section{Geological background and sample descriptions}

The East Pacific Rise from $8-10^{\circ} \mathrm{N}$ is a fast-spreading ridge segment (half-spreading rate of $5.5 \mathrm{~cm} / \mathrm{yr}$ ) bounded to the north by the Clipperton Fracture Zone and to the south by the Siqueiros Fracture Zone (Fig. 1). The OSC at $9^{\circ} 03^{\prime} \mathrm{N}$ EPR consists of two north-south trending spreading axes that overlap by $\sim 27 \mathrm{~km}$ and are offset to the right by $\sim 8 \mathrm{~km}$. Geophysical studies document 


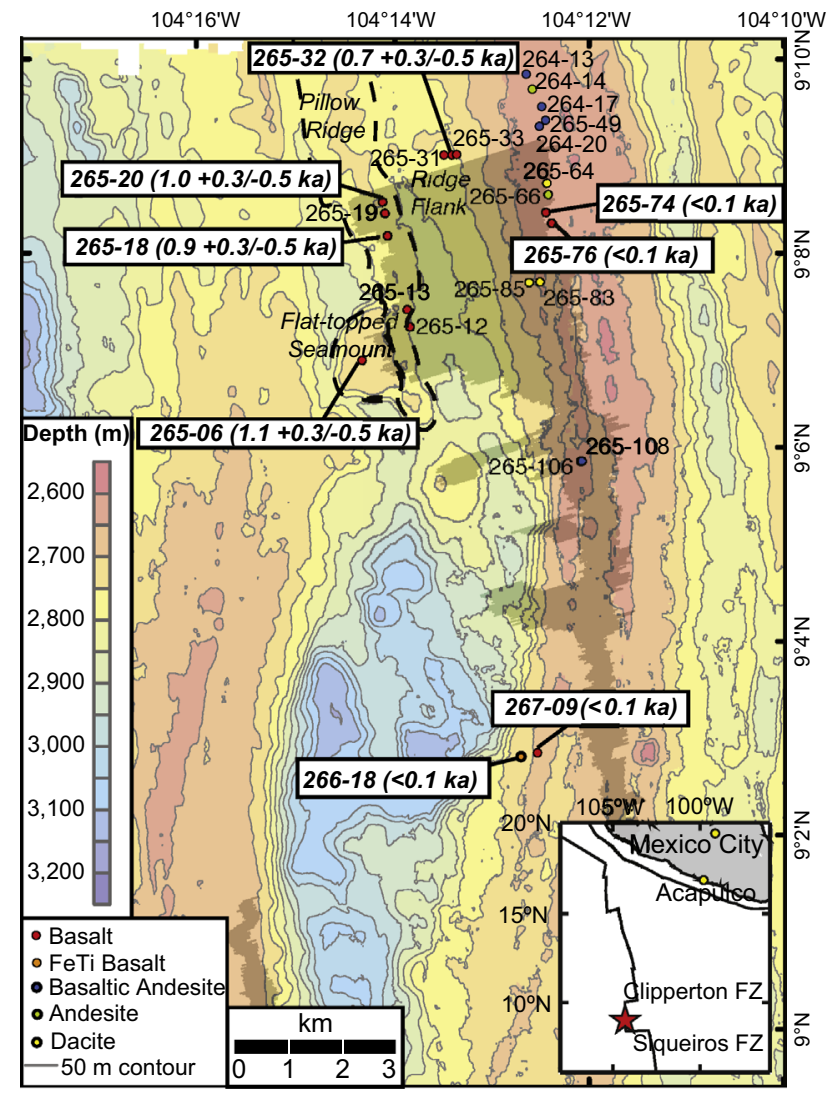

Fig. 1. Compiled bathymetric map (White et al., 2009) of the study area showing sample locations, rock types, and model ages with uncertainties. Dashed lines encircle the off-axis pillow ridge and flat-topped volcano that overlie the western extent of seismically imaged melt (shown as gray overlay; Kent et al., 2000). The inset map locates the study area.

a low velocity anomaly interpreted as melt in the uppermost mantle extending across the OSC, with the lowest velocities centered beneath the eastern limb (Dunn et al., 2000; Toomey et al., 2007), melt accumulation in the overlying crust (Singh et al., 2006), and a mid-crustal mush zone at the northern end of the overlap basin at $\sim 9^{\circ} 08^{\prime} \mathrm{N}$ (Bazin et al., 2003; Crawford and Webb, 2002). In addition, a 3-D seismic reflection study reveals a $\sim 4 \mathrm{~km}$ wide, upper-crustal melt sill beneath the eastern limb that extends westward into the northern portion of the overlap basin (Kent et al., 2000). The sill reflectors deepen to the west of the east limb axis, suggesting melt may be delivered from an off-axis asthenospheric source to the deeper, off-axis part of this melt sill. The melt sill imaged by Kent et al. (2000) is shown as a shaded area in Fig. 1 for reference. However, this melt "sill" is not clearly a continuous melt-rich region, but it is instead complex in 3-D geometry and distribution and may include a network of isolated melt-rich regions away from the melt accumulation underlying the axial graben (cf., Fig. 3d of Singh et al., 2006).

One of the objectives of the AT15-17 cruise to the OSC at $9^{\circ} 03^{\prime} \mathrm{N}$ EPR was to use the ROV Jason II to sample lavas along and across the wide melt lens (Fig. 1; Klein et al., 2007). We selected 22 of these samples for ${ }^{238} \mathrm{U}-{ }^{230} \mathrm{Th}-{ }^{226} \mathrm{Ra}-{ }^{210} \mathrm{~Pb}$ isotopic age dating. These samples span a range of tholeiitic volcanic rock compositions, including ferrobasalt, basaltic andesite (or basaltic icelandite), andesite (or icelandite; cf., Carmichael, 1964), and dacite (Wanless et al., 2010, 2011, 2012); and, tectonic settings including the axial graben, the ridge flank, and the large, axis-parallel pillow ridge and flat-topped seamount that overlie the westernmost extent of the wide melt lens (Fig. 1). Sample locations are shown in Fig. 1, sample site photos are shown in Fig. 2, and sample descriptions and compositional variations are given in Supplemental Table 1. Sample major and trace element compositions have been published elsewhere (Wanless et al., 2010, 2011, 2012).

\section{Dating lavas with U-Th-Ra disequilibria}

The half-lives of U-series nuclides ${ }^{210} \mathrm{~Pb}(22.6 \mathrm{yr}),{ }^{226} \mathrm{Ra}(1.6 \mathrm{ka})$ and ${ }^{230} \mathrm{Th}(75 \mathrm{ka})$ make them ideally suited for studying recent magmatic and volcanic processes. U-series parent/daughter nuclide pairs can fractionate during partial melting and crystallization, creating radioactive disequilibria. Radioactive decay during melt transport, crustal residence, and post-eruption aging return these nuclide pairs to a steady-state condition called "secular equilibrium," in which the activities of nuclides are equal and the activity ratios (e.g., $\left.\left({ }^{210} \mathrm{~Pb} /{ }^{226} \mathrm{Ra}\right),\left({ }^{226} \mathrm{Ra} /{ }^{230} \mathrm{Th}\right),\left({ }^{230} \mathrm{Th} /{ }^{238} \mathrm{U}\right)\right)$ are unity. Secular equilibrium is reached in roughly five half-lives following the fractionation of parent/daughter nuclides. Therefore, the presence of disequilibrium in a lava, for example $\left({ }^{210} \mathrm{~Pb} /{ }^{226} \mathrm{Ra}\right) \neq 1 \pm 0.05$ (2SE), $\left({ }^{226} \mathrm{Ra} /{ }^{230} \mathrm{Th}\right) \neq 1 \pm 0.05(2 \mathrm{SE})$, or $\left({ }^{230} \mathrm{Th} /{ }^{238} \mathrm{U}\right) \neq 1 \pm 0.01$ (2SE), limits the eruption age to $<100 \mathrm{yr}$, $<8 \mathrm{ka}$, or $<375 \mathrm{ka}$, respectively.

U-series model age dating of young MORB at the EPR is well established (Goldstein et al., 1994; Rubin and MacDougall, 1990; Sims et al., 2003; Waters et al., 2011). U-series model ages for off-axis MORB have been calculated by inferring initial activities from the youngest axial basalts and comparing these activities with the values measured in off-axis samples of unknown age. Robust application of U-series model ages requires that the young, axial lavas (of known age) and the off-axis lavas of unknown age (to be dated) derive from chemically similar mantle sources and were generated by similar petrogenetic and magmatic processes (Sims et al., 2003). While early models used measurements from one or two axial lavas to calculate the ages of older lavas (e.g., Goldstein et al., 1994), at $9^{\circ} 17^{\prime}-9^{\circ} 54^{\prime} \mathrm{N}$ EPR there are now enough young axial lavas of known age that form coherent trends of ${ }^{238} \mathrm{U}-{ }^{230} \mathrm{Th}-{ }^{226} \mathrm{Ra}$ disequilibria (Sims et al., 2002, 2003) such that this technique is ever more robust (Sims et al., 2003; Waters et al., 2011).

\section{Results}

\section{1. ${ }^{87} \mathrm{Sr} /{ }^{86} \mathrm{Sr}$ and ${ }^{143} \mathrm{Nd} /{ }^{144} \mathrm{Nd}$ Isotope compositions}

Source lithology can significantly influence the magnitude of ${ }^{238} \mathrm{U}^{230}{ }^{230} \mathrm{Th}-{ }^{226}$ Ra disequilibria (e.g., Elkins et al., 2011; Lundstrom et al., 1995; Waters et al., 2011). All measured east limb lavas have uniform ${ }^{87} \mathrm{Sr} /{ }^{86} \mathrm{Sr}$ and ${ }^{143} \mathrm{Nd} /{ }^{144} \mathrm{Nd}$ isotope compositions (Table 1), within analytical uncertainties, and are consistent with isotopic compositions previously reported for east limb lavas (Wanless et al., 2010) and basalts from $9^{\circ} 17^{\prime} \mathrm{N}-9^{\circ} 54^{\prime} \mathrm{N}$ EPR (Goss et al., 2010 ; Sims et al., 2002, 2003; Waters et al., 2011). This isotopic homogeneity indicates that their time-integrated parent/daughter $\mathrm{Rb} / \mathrm{Sr}$ and $\mathrm{Sm} / \mathrm{Nd}$ are uniform, suggesting that these lavas either come from a homogeneous mantle source that is similar to the mantle source for lavas from $9^{\circ} 17^{\prime}-9^{\circ} 54^{\prime} \mathrm{N}$ EPR, or that any melts derived from compositional heterogeneities are diluted and masked by thorough mixing (cf. Waters et al., 2011).

\subsection{U-series disequilibria}

For submarine lavas, $\left({ }^{234} \mathrm{U} /{ }^{238} \mathrm{U}\right)$ is a sensitive indicator of alteration because seawater is significantly enriched in ${ }^{234} \mathrm{U}$ relative to ${ }^{238} \mathrm{U}$ (seawater $\left({ }^{234} \mathrm{U} /{ }^{238} \mathrm{U}\right)=1.14 \pm 0.03$; Thurber, 1962). All but three samples measured have $\left({ }^{234} \mathrm{U} /{ }^{238} \mathrm{U}\right)=1.000 \pm 0.5 \%$ 

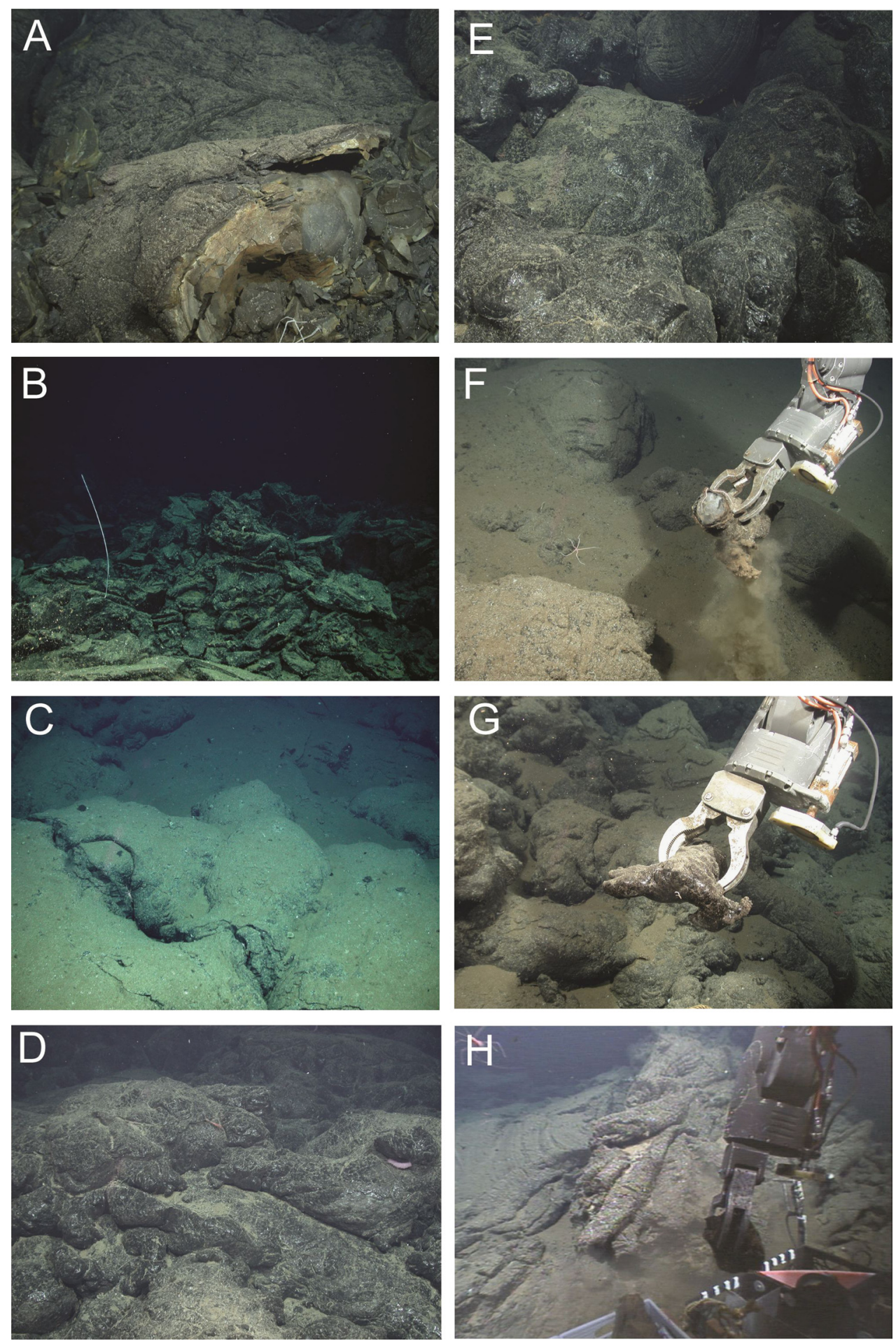

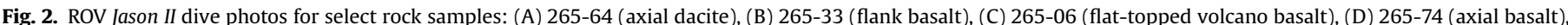

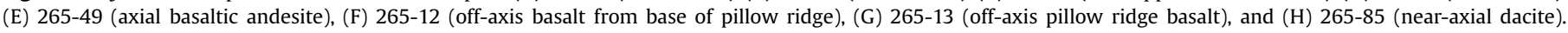
In general, off-axis basalts $(B, C, F, G)$ appear older than samples collected within the axial graben $(A, D, E)$.

(Table 1), indicating that these samples have not suffered significant secondary alteration due to seawater-rock interaction following eruption. Samples 265-74, 265-06, and 265-13 have $\left({ }^{234} U /{ }^{238} U\right) \sim 1.006-1.008$, but the close similarity of $U$ abundances and $\left({ }^{238} \mathrm{U} /{ }^{232} \mathrm{Th}\right)$ for these samples with that of other samples collected nearby with $\left({ }^{234} \mathrm{U} /{ }^{238} \mathrm{U}\right)=1.000 \pm 0.5 \%$ indicates that these samples have also not been significantly affected by alteration due to seawater-rock interaction.
All samples have ${ }^{230} \mathrm{Th}$ excesses (i.e., $\left({ }^{230} \mathrm{Th} /{ }^{238} \mathrm{U}\right)>1$ ), which increase from basalt (9-14\%), to basaltic andesite (10-16\%), to dacite (16-18\%). However, as a group, all samples have ${ }^{230} \mathrm{Th}$ excesses similar to the range measured for young N-MORB from $9^{\circ} 17^{\prime} \mathrm{N}-$ $9^{\circ} 54^{\prime} \mathrm{N}$ (11-19\%; Fig. 3A, Table 1). Similarly, all east limb samples have $\left({ }^{230} \mathrm{Th} /{ }^{232} \mathrm{Th}\right)$ and $\left({ }^{238} \mathrm{U} /{ }^{232} \mathrm{Th}\right)$ that are similar to those for axial and off-axis N-MORB samples from $9^{\circ} 17^{\prime}-9^{\circ} 54^{\prime} \mathrm{N}$ EPR (Sims et al., 2002, 2003; Waters et al., 2011). 
Table 1

$\left({ }^{230} \mathrm{Th} /{ }^{232} \mathrm{Th}\right),\left({ }^{230} \mathrm{Th} /{ }^{238} \mathrm{U}\right),\left({ }^{226} \mathrm{Ra} /{ }^{230} \mathrm{Th}\right),\left({ }^{210} \mathrm{~Pb} /{ }^{226} \mathrm{Ra}\right),\left({ }^{234} \mathrm{U} /{ }^{238} \mathrm{U}\right),{ }^{87} \mathrm{Sr} /{ }^{86} \mathrm{Sr},{ }^{143} \mathrm{Nd} /{ }^{144} \mathrm{Nd}$, and $\mathrm{U}, \mathrm{Th},{ }^{226} \mathrm{Ra}$ and ${ }^{210} \mathrm{~Pb}$ concentrations of $9^{\circ} 03^{\prime} \mathrm{N}$ EPR overlapping spreading center east limb lavas ${ }^{\mathrm{a}}$.

\begin{tabular}{|c|c|c|c|c|c|c|c|c|c|c|c|c|c|c|}
\hline Sample & $\begin{array}{l}\mathrm{Th}^{\mathrm{b}} \\
(\mathrm{ppm})\end{array}$ & $\begin{array}{l}\mathrm{U}^{\mathrm{b}} \\
(\mathrm{ppm})\end{array}$ & $\left({ }^{238} \mathrm{U} /{ }^{232} \mathrm{Th}\right)^{\mathrm{c}}$ & $\mathrm{Th} / \mathrm{U}$ & $\left({ }^{230} \mathrm{Th} /{ }^{232} \mathrm{Th}\right)^{\mathrm{d}}$ & $\left({ }^{230} \mathrm{Th} /{ }^{238} \mathrm{U}\right)^{\mathrm{d}}$ & {$\left[{ }^{226} \mathrm{Ra}\right] \mathrm{fg} / \mathrm{g}^{\mathrm{e}}$} & $\left({ }^{226} \mathrm{Ra} / /^{230} \mathrm{Th}\right)^{\mathrm{e}}$ & $\begin{array}{l}{ }^{210} \mathrm{~Pb}^{\mathrm{f}} \\
(\mathrm{dpm} / \mathrm{g})\end{array}$ & $\left({ }^{210} \mathrm{~Pb} / 226 \mathrm{Ra}\right)^{\mathrm{f}}$ & $\left({ }^{234} U / /^{238} U\right)^{g}$ & ${ }^{87} \mathrm{Sr} /{ }^{86} \mathrm{Sr}^{\mathrm{h}}$ & ${ }^{143} \mathrm{Nd} /{ }^{144} \mathrm{Nd}^{\mathrm{h}}$ & $\varepsilon_{N d}^{\mathrm{h}}$ \\
\hline \multicolumn{15}{|l|}{ Basalts } \\
\hline $265-74$ & $0.161+2^{i}$ & $0.066+1$ & 1.241 & & \\
\hline $265-76(1)$ & $0.185 \pm 3$ & $0.075 \pm 1$ & 1.233 & 2.460 & $1.370 \pm 2$ & 1.111 & $67.8 \pm 9$ & 2.41 & $0.209 \pm 10$ & 1.40 & $0.9930 \pm 11$ & 0.702528 & 0.513140 & 9.79 \\
\hline $265-76(2)$ & $0.183 \pm 3$ & $0.072 \pm 1$ & 1.202 & 2.525 & & 1.140 & & & & & & & & \\
\hline average & 0.184 & 0.074 & 1.218 & 2.493 & 1.370 & 1.126 & 67.8 & 2.43 & & & 0.9930 & & & \\
\hline $266-18$ & $0.177 \pm 2$ & $0.072 \pm 1$ & 1.238 & 2.451 & $1.366 \pm 3$ & 1.104 & $64.1 \pm 10$ & 2.39 & $0.177 \pm 8$ & 1.26 & $1.0004 \pm 12$ & 0.702491 & 0.513168 & 10.34 \\
\hline $267-09$ & $0.158 \pm 2$ & $0.065 \pm 1$ & 1.244 & 2.438 & $1.366 \pm 3$ & 1.098 & $50.7 \pm 7$ & 2.10 & $0.166 \pm 9$ & 1.49 & $1.0008 \pm 12$ & 0.702451 & $\underline{0.513186}$ & 10.69 \\
\hline \multicolumn{15}{|l|}{ Ridge Flank } \\
\hline $265-31$ & & & & & & & & & & & & 0.702473 & 0.513152 & 10.03 \\
\hline \multirow[t]{4}{*}{$265-32$} & $0.149 \pm 2$ & $0.061 \pm 1$ & 1.248 & 2.431 & $1.405 \pm 3$ & 1.126 & $45.4 \pm 7$ & 1.96 & & & $1.0014 \pm 9$ & $\underline{0.702483}$ & $\underline{0.513151}$ & 10.01 \\
\hline & & & & & & & & & & & & $\overline{0.702582}$ & $\overline{0.513156}$ & 10.11 \\
\hline & & & & & & & & & & & & 0.702482 & & \\
\hline & & & & & & & & & & & & 0.702474 & & \\
\hline $265-33$ & $0.191 \pm 2$ & $0.078 \pm 1$ & 1.234 & 2.458 & & & $58.4 \pm 7$ & & & & $1.0048 \pm 9$ & 0.702480 & 0.513156 & 10.11 \\
\hline $265-12$ & $0.283 \pm 4$ & $0.111 \pm 2$ & 1.196 & 2.537 & & & $41.4 \pm 5$ & & & & $1.0038 \pm 6$ & & & \\
\hline \multicolumn{15}{|c|}{ Flat-Topped Volcano } \\
\hline $265-06$ & $0.156 \pm 2$ & $0.065 \pm 1$ & 1.272 & 2.385 & $1.387 \pm 7$ & 1.091 & $43.4 \pm 5$ & 1.84 & & & $1.0058 \pm 7$ & & 0.513156 & 10.10 \\
\hline \multicolumn{15}{|l|}{ Pillow Ridge } \\
\hline $265-13$ & $0.149 \pm 2$ & $0.062 \pm 1$ & 1.273 & 2.383 & & & $46.9 \pm 6$ & & & & $1.0055 \pm 13$ & & & \\
\hline $265-18$ & $0.154 \pm 2$ & $0.065 \pm 1$ & 1.275 & 2.379 & $1.404 \pm 9$ & 1.101 & $45.0 \pm 8$ & 1.87 & & & $1.0040 \pm 7$ & 0.702487 & 0.513190 & 10.8 \\
\hline $265-19$ & $0.153 \pm 2$ & $0.064 \pm 1$ & 1.275 & 2.379 & & & $46.4 \pm 6$ & & & & $1.0039 \pm 10$ & & & \\
\hline $265-20$ & $0.154 \pm 2$ & $0.065 \pm 1$ & 1.275 & 2.378 & $1.409 \pm 10$ & 1.105 & $44.5 \pm 5$ & 1.84 & & & $1.0044 \pm 8$ & & & \\
\hline \multicolumn{15}{|c|}{ Basaltic Andesites } \\
\hline \multicolumn{15}{|c|}{ Axial } \\
\hline $264-13$ & $0.603 \pm 7$ & $0.238 \pm 3$ & 1.196 & 2.537 & $1.381 \pm 2$ & 1.155 & $137.6 \pm 15$ & 1.49 & & & $1.0024 \pm 8$ & 0.702512 & 0.513164 & 10.26 \\
\hline $264-17$ & $0.369 \pm 5$ & $0.148 \pm 3$ & 1.215 & 2.497 & $1.381 \pm 3$ & 1.136 & $100.4 \pm 11$ & 1.77 & $0.234 \pm 10$ & 1.06 & $1.0040 \pm 8$ & 0.702468 & 0.513151 & 10.01 \\
\hline \multirow{2}{*}{$264-20$} & $0.588 \pm 7$ & $0.230 \pm 3$ & 1.187 & 2.555 & $1.382 \pm 3$ & 1.164 & $115.9 \pm 19$ & 1.28 & $0.315 \pm 12$ & 1.24 & $0.9985 \pm 5$ & 0.702499 & 0.513144 & 9.87 \\
\hline & $0.584 \pm 8$ & $0.229 \pm 3$ & 1.190 & 2.549 & & & & & & & & 0.702438 & $\overline{0.513179}$ & 10.6 \\
\hline average & 0.586 & 0.230 & 1.189 & 2.552 & 1.382 & 1.163 & 115.9 & 1.29 & 0.315 & 1.24 & 0.9985 & & & \\
\hline \multirow[t]{5}{*}{$265-49$} & $0.390 \pm 5$ & $0.156 \pm 3$ & 1.216 & 2.494 & $1.374 \pm 2$ & 1.130 & $72.0 \pm 11$ & 1.21 & $0.235 \pm 12$ & 1.49 & $1.0013 \pm 11$ & 0.702498 & $\underline{0.513150}$ & 9.98 \\
\hline & & & & & & & & & & & & 0.702689 & $\underline{0.513157}$ & 10.12 \\
\hline & & & & & & & & & & & & $\overline{0.702487}$ & & \\
\hline & & & & & & & & & & & & 0.702475 & & \\
\hline & & & & & & & & & & & & 0.702438 & 0.513196 & 10.90 \\
\hline \multirow{2}{*}{$265-106$} & $0.558 \pm 8$ & $0.230 \pm 4$ & 1.252 & 2.423 & $1.378 \pm 2$ & 1.101 & $140.9 \pm 20$ & 1.65 & $0.314 \pm 12$ & 1.02 & $1.0038 \pm 12$ & 0.702520 & $\underline{0.513166}$ & 10.30 \\
\hline & & & & & & & & & & & & 0.702564 & $\underline{0.513157}$ & 10.12 \\
\hline \multirow[t]{2}{*}{$265-108$} & $0.569 \pm 9$ & $0.235 \pm 6$ & 1.253 & 2.421 & $1.384 \pm 3$ & 1.104 & $117.0 \pm 20$ & 1.34 & $0.302 \pm 12$ & 1.18 & $0.9963 \pm 14$ & 0.702682 & $\underline{0.513150}$ & 9.99 \\
\hline & & & & & & & & & & & & 0.702519 & $\overline{0.513156}$ & 10.10 \\
\hline \multicolumn{15}{|c|}{ Andesites/Dacites } \\
\hline \multicolumn{15}{|l|}{ Axial } \\
\hline \multirow[t]{2}{*}{$264-14$} & & & & & & & & & & & & 0.702519 & 0.513160 & 10.19 \\
\hline & & & & & & & & & & & & 0.702428 & 0.513153 & 10.0 \\
\hline $265-66$ & $1.468 \pm 18$ & $0.573 \pm 8$ & 1.184 & 2.562 & $1.373 \pm 2$ & 1.159 & $312.2 \pm 38$ & 1.39 & $0.680 \pm 20$ & 0.99 & $1.0028 \pm 6$ & 0.702493 & & \\
\hline \multirow[t]{2}{*}{$265-64$} & $1.559 \pm 20$ & $0.608 \pm 9$ & 1.183 & 2.565 & $1.378 \pm 2$ & 1.166 & $329.7 \pm 39$ & 1.37 & & & $1.0035 \pm 6$ & 0.702534 & 0.513158 & 10.14 \\
\hline & & & & & & & & & & & & 0.702576 & 0.513185 & 10.7 \\
\hline Near-Axial & & & & & & & & & & & & & & \\
\hline $265-83$ & $1.965 \pm 24$ & $0.756 \pm 11$ & 1.167 & 2.599 & $1.349 \pm 2$ & 1.156 & $307.1 \pm 34$ & 1.04 & & & $1.0041 \pm 4$ & 0.702524 & 0.513159 & 10.16 \\
\hline & & & & & & & & & & & & 0.702534 & 0.513147 & 9.9 \\
\hline $265-85$ & $2.334 \pm 32$ & $0.900 \pm 14$ & 1.170 & 2.594 & $1.374 \pm 2$ & 1.175 & $352.9 \pm 45$ & 0.99 & & & $1.0032 \pm 7$ & & 0.513165 & 10.27 \\
\hline & & & & & & & & & & & & 0.702481 & 0.513148 & 9.9 \\
\hline
\end{tabular}




\begin{tabular}{|c|c|c|c|c|c|c|c|c|c|c|c|c|c|}
\hline Sample & $\begin{array}{l}\mathrm{Th}^{\mathrm{b}} \\
(\mathrm{ppm})\end{array}$ & $\begin{array}{l}\mathrm{U}^{\mathrm{b}} \\
(\mathrm{ppm})\end{array}$ & $\left({ }^{238} \mathrm{U} / /^{232} \mathrm{Th}\right)^{\mathrm{c}}$ & $\mathrm{Th} / \mathrm{U}$ & $\left({ }^{230} \mathrm{Th} /{ }^{232} \mathrm{Th}\right)^{\mathrm{d}}$ & $\left({ }^{230} \mathrm{Th} /{ }^{238} \mathrm{U}\right)^{\mathrm{d}}$ & {$\left[{ }^{226} \mathrm{Ra}\right] \mathrm{fg} / \mathrm{g}^{\mathrm{e}}$} & $\left({ }^{226} \mathrm{Ra} /{ }^{230} \mathrm{Th}\right)^{\mathrm{e}}$ & 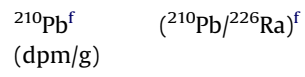 & $\left({ }^{234} U /{ }^{238} U\right)^{g}$ & ${ }^{87} \mathrm{Sr} /{ }^{86} \mathrm{Sr}^{\mathrm{h}}$ & ${ }^{143} \mathrm{Nd} /{ }^{144} \mathrm{Nd}^{\mathrm{h}}$ & $\varepsilon_{N d}^{\mathrm{h}}$ \\
\hline \multicolumn{14}{|c|}{ Standards $^{\mathrm{j}}$} \\
\hline \multirow[t]{6}{*}{$\mathrm{TML} / 3$} & $30.38 \pm 38$ & $10.82 \pm 18$ & 1.078 & 2.814 & $1.082 \pm 1$ & 1.002 & $3669 \pm 55$ & 1.01 & & $1.0018 \pm 5$ & & & \\
\hline & $30.63 \pm 38$ & $10.78 \pm 17$ & 1.067 & 2.842 & $1.083 \pm 2$ & 1.002 & $3675 \pm 44$ & 1.01 & & $1.0013 \pm 5$ & & & \\
\hline & & & & & $1.078 \pm 3$ & 0.998 & & & & & & & \\
\hline & & & & & $1.081 \pm 3$ & 1.000 & $3709_{ \pm 55}$ & 1.02 & & & & & \\
\hline & & & & & $1.073 \pm 2$ & 0.993 & $3698 \pm 43$ & 1.02 & & & & & \\
\hline & & & & & $1.074 \pm 3$ & 0.994 & & & & & & & \\
\hline Accepted & 30.50 & 10.79 & 1.073 & 2.827 & 1.070 & 0.998 & 3604 & 0.99 & & 1.0010 & & & \\
\hline \multirow[t]{2}{*}{$\mathrm{AThO} / 3$} & $7.52 \pm 10$ & $2.264 \pm 33$ & 0.913 & 3.322 & $1.017 \pm 2$ & 1.114 & $861.4 \pm 12$ & 1.01 & & $1.0018 \pm 5$ & & & \\
\hline & & & & & $1.028 \pm 4$ & 1.124 & $834.6 \pm 16$ & 0.98 & & & & & \\
\hline Accepted & 7.44 & 2.26 & 0.920 & 3.292 & 1.015 & 1.104 & 843.7 & 1.00 & & 1.0020 & & & \\
\hline
\end{tabular}

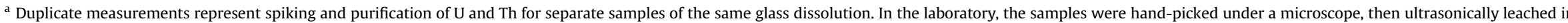

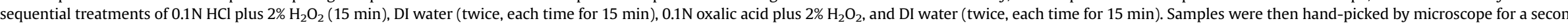

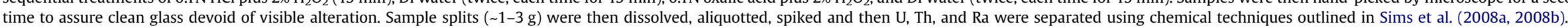

${ }^{\mathrm{b}}[\mathrm{U}]$ and [Th] were measured by ID-ICP-MS using the Thermo Finnigan Element2. Measurement reproducibility $(2 \sigma)$ for $[\mathrm{U}]$ and [Th] are estimated at $<2.1 \%$ and $<2.5 \%$, respectively

${ }^{c}$ ( ) Denotes activity. $\lambda_{238}=1.551 \times 10^{-10} \mathrm{yr}^{-1} ; \lambda_{232}=4.948 \times 10^{-11} \mathrm{yr}^{-1} ;\left({ }^{238} \mathrm{U} /{ }^{232} \mathrm{Th}\right.$ ) errors $(2 \sigma)$ range from $1.9-2.9 \%$ and do not include uncertainties in $\lambda_{238}(0.07 \%)$ or $\lambda_{232}(0.5 \%)$.

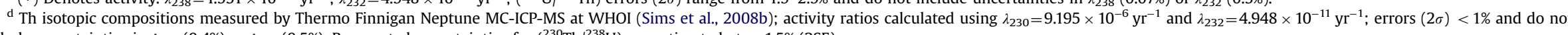
nclude uncertainties in $\lambda_{230}(0.4 \%)$ or $\lambda_{232}(0.5 \%)$. Propagated uncertainties for $\left({ }^{230} \mathrm{Th} / 38 \mathrm{U}\right.$ ) are estimated at $<1.5 \%$ (2SE).

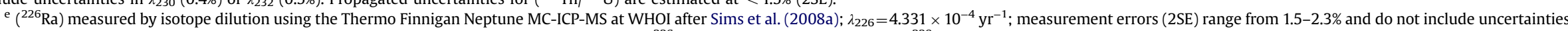
in $\lambda_{226}(0.4 \%)$ or $\lambda_{230}$. For all samples accuracy is limited by uncertainties $(2 \sigma ; 1.5 \%)$ on the NBS ${ }^{226}$ Ra standard used to calibrate the ${ }^{228}$ Ra spike.

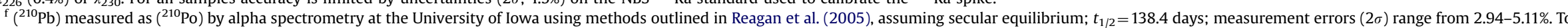

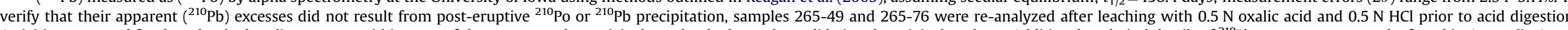
Activities measured for these leached replicates were within error of those measured on original non-leached samples, validating the original analyses. Additional analytical details of ${ }^{210} \mathrm{~Pb}$ measurements can be found in Appendix A.

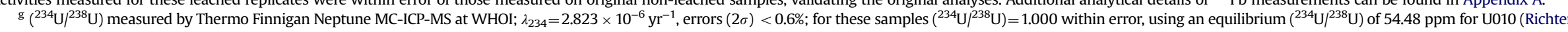
and Goldberg, 2003). U010 was used as a bracketing standard for all sample measurements to determine mass bias.

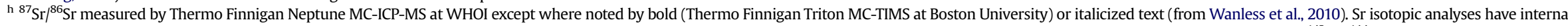

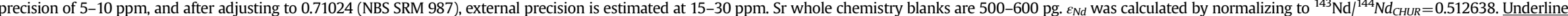

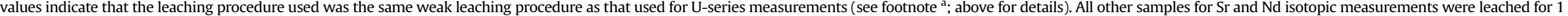
in $2.5 \mathrm{~N} \mathrm{HCl}$ at $100^{\circ} \mathrm{C}$.

${ }^{\mathrm{i}}$ Errors are sample measurement reproducibility $(2 \sigma)$ on last digit(s) given.

${ }^{\mathrm{j}}$ Accepted values for $\left.{ }^{230} \mathrm{Th} /{ }^{238} \mathrm{U}\right)$ are from Sims et al. (2008a). AThO and TML are $\left({ }^{226} \mathrm{Ra} /{ }^{230} \mathrm{Th}\right)$ equilibrium standards; the averages of results from Sims et al. (2008b) are shown for comparison. 
All samples have ${ }^{226} \mathrm{Ra}$ excesses (i.e., $\left({ }^{226} \mathrm{Ra} /{ }^{230} \mathrm{Th}\right)>1$ ), with the exception of two dacite samples, 265-83 and 265-85 (Fig. 3, Table 1$)$. These two dacite samples have equilibrium $\left({ }^{226} \mathrm{Ra} /{ }^{230} \mathrm{Th}\right)$, despite the fact that in dive photographs the seafloor where they were collected appears as young as the seafloor from which the lavas with ${ }^{226} \mathrm{Ra}$ excesses were collected (Fig. $2 \mathrm{H}$, Fig. 3). Pillow ridge basalts appear variably sediment covered in seafloor photos (Fig. 2C, G) and have $\left({ }^{226} \mathrm{Ra} /{ }^{230} \mathrm{Th}\right)$ of $\sim 1.81-1.87$. A basalt recovered from the western flank of the east limb (265-32; Fig. 2B) has slightly higher $\left({ }^{226} \mathrm{Ra} /{ }^{230} \mathrm{Th}\right)$ of $\sim 1.96$. Axial basalts appear fresh in dive photos (Fig. 2D) and have the highest $\left({ }^{226} \mathrm{Ra} /{ }^{230} \mathrm{Th}\right)$ of $\sim 2.10-$ 2.43 , which approaches the zero-age $\left({ }^{226} \mathrm{Ra} /{ }^{230} \mathrm{Th}\right)$ values of $1991-$ 92 eruption samples with similar $\left({ }^{230} \mathrm{Th} /{ }^{238} \mathrm{U}\right)$ at $9^{\circ} 50^{\prime} \mathrm{N}$ EPR (2.66-2.89; Sims et al., 2002, Fig. 3A). Basaltic andesites from the axial graben appear as fresh as axial basalts (Fig. 2E), but they have lower $\left({ }^{226} \mathrm{Ra} /{ }^{230} \mathrm{Th}\right)$ of $\sim 1.21-1.77$. Dacite samples $265-64$ and $265-$ 66 also appear fresh in dive photos yet they have low $\left({ }^{226} \mathrm{Ra} /{ }^{230} \mathrm{Th}\right)$ of $\sim 1.35-1.36$ (Fig. 3A). Because the half-life of ${ }^{226} \mathrm{Ra}$ is sufficiently short with respect to the half-life of ${ }^{230} \mathrm{Th}$, the $\left({ }^{230} \mathrm{Th} /{ }^{232} \mathrm{Th}\right)$ and $\left({ }^{230} \mathrm{Th} /{ }^{238} \mathrm{U}\right)$ of samples with ${ }^{226} \mathrm{Ra}$ excesses are essentially unchanged since eruption. Unlike at $9^{\circ} 17^{\prime} \mathrm{N}-9^{\circ} 54^{\prime} \mathrm{N}$ EPR, demonstrably zero-age basalts (with respect to the half-lives of ${ }^{226} \mathrm{Ra}$ and ${ }^{230} \mathrm{Th}$ ) from the east limb of the $9^{\circ} 03^{\prime} \mathrm{N}$ OSC are limited to four samples from this study with measured $\left({ }^{210} \mathrm{~Pb} /{ }^{226} \mathrm{Ra}\right)>1$. As is the case at $9^{\circ} 17^{\prime}-9^{\circ} 54^{\prime} \mathrm{N}$ EPR, we observe variable $\left({ }^{226} \mathrm{Ra} /{ }^{230} \mathrm{Th}\right)$ excesses at a given $\left({ }^{230} \mathrm{Th} /{ }^{238} \mathrm{U}\right)$ for zero-age basalts, but unlike at $9^{\circ} 17^{\prime}-9^{\circ} 54^{\prime} \mathrm{N}$, where U-series measurements on a much larger suite of zero-age basalts show inversely correlated $\left({ }^{226} \mathrm{Ra} /{ }^{230} \mathrm{Th}\right)$ and $\left({ }^{230} \mathrm{Th} /{ }^{238} \mathrm{U}\right)$, all basalts have similar $\left({ }^{230} \mathrm{Th} /{ }^{238} \mathrm{U}\right)$ excesses (Fig. 3). Thus, we use the average of the four zero-age axial samples to estimate the initial ${ }^{226} \mathrm{Ra}-{ }^{230} \mathrm{Th}$ and ${ }^{230} \mathrm{Th}-{ }^{238} \mathrm{U}$ disequilibria for calculating model ages for $9^{\circ} 03^{\prime} \mathrm{N}$ east limb lavas.

Ten axial lavas were measured for $\left({ }^{210} \mathrm{~Pb}\right)$ and have $\left({ }^{210} \mathrm{~Pb}\right)$ ranging from $0.166-0.680 \mathrm{dpm} / \mathrm{g}$. Seven of ten lavas have significant ${ }^{210} \mathrm{~Pb}$ excesses [i.e., $\left({ }^{210} \mathrm{~Pb} /{ }^{226} \mathrm{Ra}\right)>1$ ]. The short half-life of ${ }^{210} \mathrm{~Pb}$ means that the $\left({ }^{226} \mathrm{Ra} /{ }^{230} \mathrm{Th}\right)$ disequilibria in these lavas can also be considered unchanged since eruption. $\left({ }^{210} \mathrm{~Pb}\right)$ is wellcorrelated with $\mathrm{Th}, \mathrm{U}$, and ${ }^{226} \mathrm{Ra}$ abundances, with the most depleted basalts having the lowest $\left({ }^{210} \mathrm{~Pb}\right)$ and dacite sample 265-66 having the highest $\left({ }^{210} \mathrm{~Pb}\right)$ (Fig. 4). $\left({ }^{210} \mathrm{~Pb} /{ }^{226} \mathrm{Ra}\right)$ ranges from $0.99-1.69$, with basalts having the highest $\left({ }^{210} \mathrm{~Pb} /{ }^{226} \mathrm{Ra}\right)$ (1.26-1.69), basaltic andesites having intermediate $\left({ }^{210} \mathrm{~Pb} /{ }^{226} \mathrm{Ra}\right)$ (from equilibrium to 1.49 ) and the dacite having equilibrium $\left({ }^{210} \mathrm{~Pb} /{ }^{226} \mathrm{Ra}\right)$. There appears to be no relationship between $\left({ }^{210} \mathrm{~Pb} /{ }^{226} \mathrm{Ra}\right)$ and $\left({ }^{226} \mathrm{Ra} /{ }^{230} \mathrm{Th}\right),\left({ }^{230} \mathrm{Th} /{ }^{232} \mathrm{Th}\right)$, and $\left({ }^{230} \mathrm{Th} /{ }^{238} \mathrm{U}\right)$. Correlations between $\left({ }^{210} \mathrm{~Pb} /{ }^{226} \mathrm{Ra}\right)$ and ${ }^{226} \mathrm{Ra}$, Th, and $\mathrm{U}$ abundances are at best weakly inverse (Fig. 4A). It is important to note that post-eruption decay likely decreased $\left({ }^{210} \mathrm{~Pb} /{ }^{226} \mathrm{Ra}\right)$ values towards equilibrium in some or all of these lavas following eruption. Thus, correlations are not necessarily expected, and the apparent correlations might be purely coincidental.

\section{Discussion}

\subsection{The origin of $\left({ }^{210} \mathrm{~Pb} /{ }^{226} \mathrm{Ra}\right)$ excesses in axial lavas}

One of the most interesting and puzzling features of the data set is the presence of large ${ }^{210} \mathrm{~Pb}$ excesses in both axial basalt and basaltic andesite lavas. To date, the sparse published studies of MORB have reported predominantly relatively small ${ }^{210} \mathrm{~Pb}$ deficits [i.e., $\left({ }^{210} \mathrm{~Pb} /{ }^{226} \mathrm{Ra}\right)$ as low as 0.86] (Bergmanis et al., 2007; Rubin et al., 2005), although recent work has indicated the presence of small ${ }^{210} \mathrm{~Pb}$ excesses $(\sim 10 \%)$ in young MORB from the Axial Seamount on the Juan de Fuca Ridge (Dreyer et al., 2009; Rubin et al., 2005), and ${ }^{210} \mathrm{~Pb}$ excesses have been observed in arc lavas (e.g.,
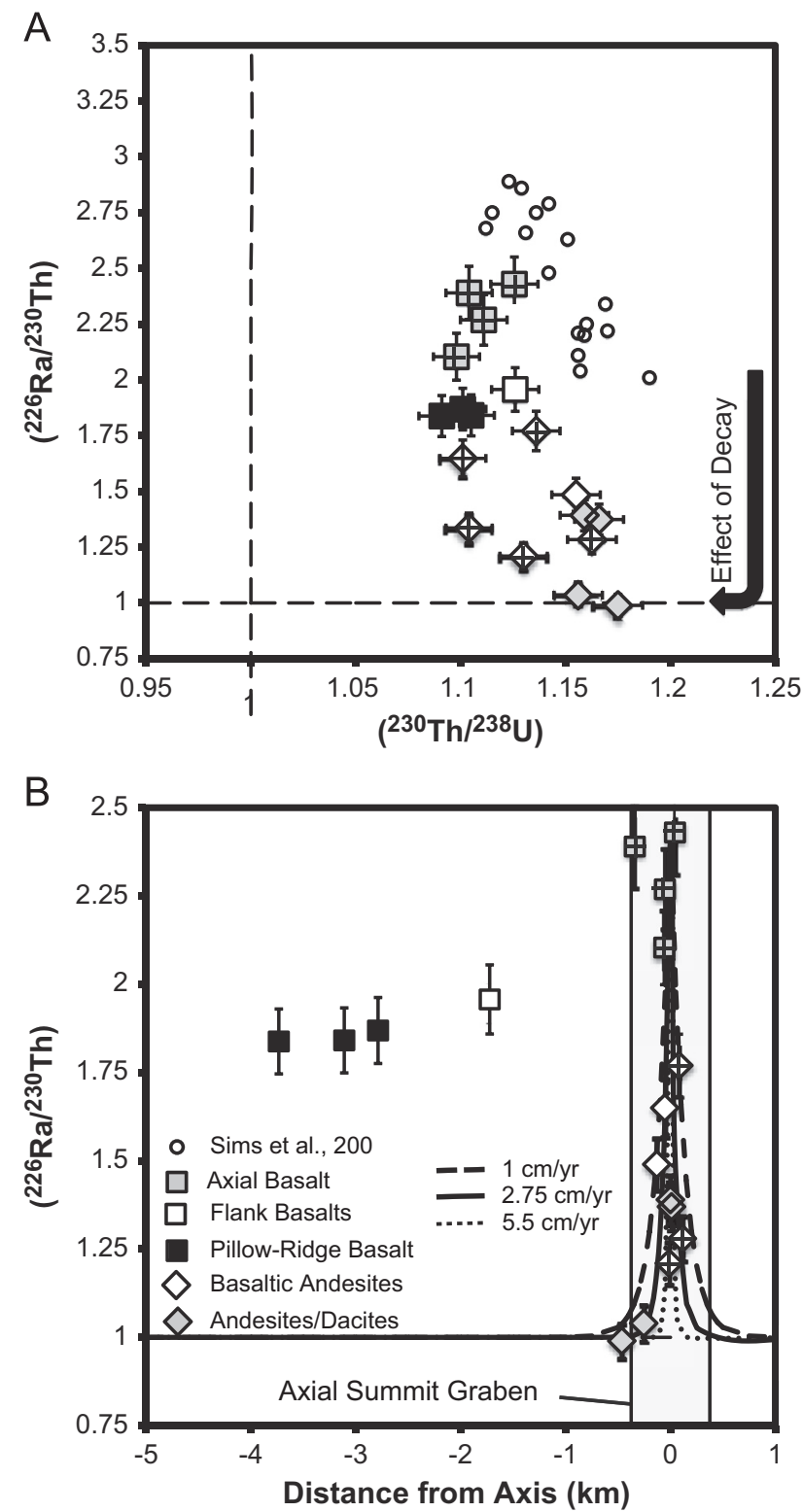

Fig. 3. (A) Variations in $\left({ }^{230} \mathrm{Th} /{ }^{238} \mathrm{U}\right)$ versus $\left({ }^{226} \mathrm{Ra} /{ }^{230} \mathrm{Th}\right)$ for east limb lavas. Zeroage axial lavas from $9^{\circ} 17^{\prime}-9^{\circ} 54^{\prime} \mathrm{N}$ EPR (Sims et al., 2002) are shown for comparison. The effect of decay is a decrease of $\left({ }^{226} \mathrm{Ra} /{ }^{230} \mathrm{Th}\right)$ with no measurable change in $\left({ }^{230} \mathrm{Th} /{ }^{238} \mathrm{U}\right)$ and is shown as a vertical trajectory. (B) Plot of distance from the axial graben center vs. $\left({ }^{226} \mathrm{Ra} /{ }^{230} \mathrm{Th}\right)$. Dashed, solid, and dotted lines represent expected changes in $\left({ }^{226} \mathrm{Ra} /{ }^{230} \mathrm{Th}\right)$ due to aging at half-spreading rates of $1,2.75$, and $5.5 \mathrm{~cm} / \mathrm{yr}$, respectively. Initial $\left({ }^{226} \mathrm{Ra} /{ }^{230} \mathrm{Th}\right)$ at the axial graben center is assumed to be 2.45 . Crosses in symbols denote those samples with measurable $\left({ }^{210} \mathrm{~Pb} /{ }^{226} \mathrm{Ra}\right)$ disequilibria.

Berlo et al., 2006; Kayzar et al., 2009; Reagan et al., 2006; Turner et al., 2004).

The ${ }^{210} \mathrm{~Pb}$ deficits previously observed in MORB are thought to result from partial melting of the mantle (Rubin et al., 2005). In contrast, ${ }^{210} \mathrm{~Pb}$ excesses are less easily explained by mantle melting, as Ra is significantly more incompatible than $\mathrm{Pb}$ during mantle melting (Blundy and Wood, 2003). ${ }^{210} \mathrm{~Pb}$ excesses could be produced by preferential melting of plagioclase or sulfide minerals in the mantle or crust (perhaps from melt-rock reaction), as $\mathrm{Pb}$ is expected to behave more compatibly than $\mathrm{Ra}$ in both plagioclase and sulfide minerals, but these minerals would need to have existing ${ }^{210} \mathrm{~Pb}$ excesses due to either young age or an increase in $\left({ }^{210} \mathrm{~Pb} /{ }^{226} \mathrm{Ra}\right)$ by diffusion (e.g., Van Orman and Saal, 2009). 

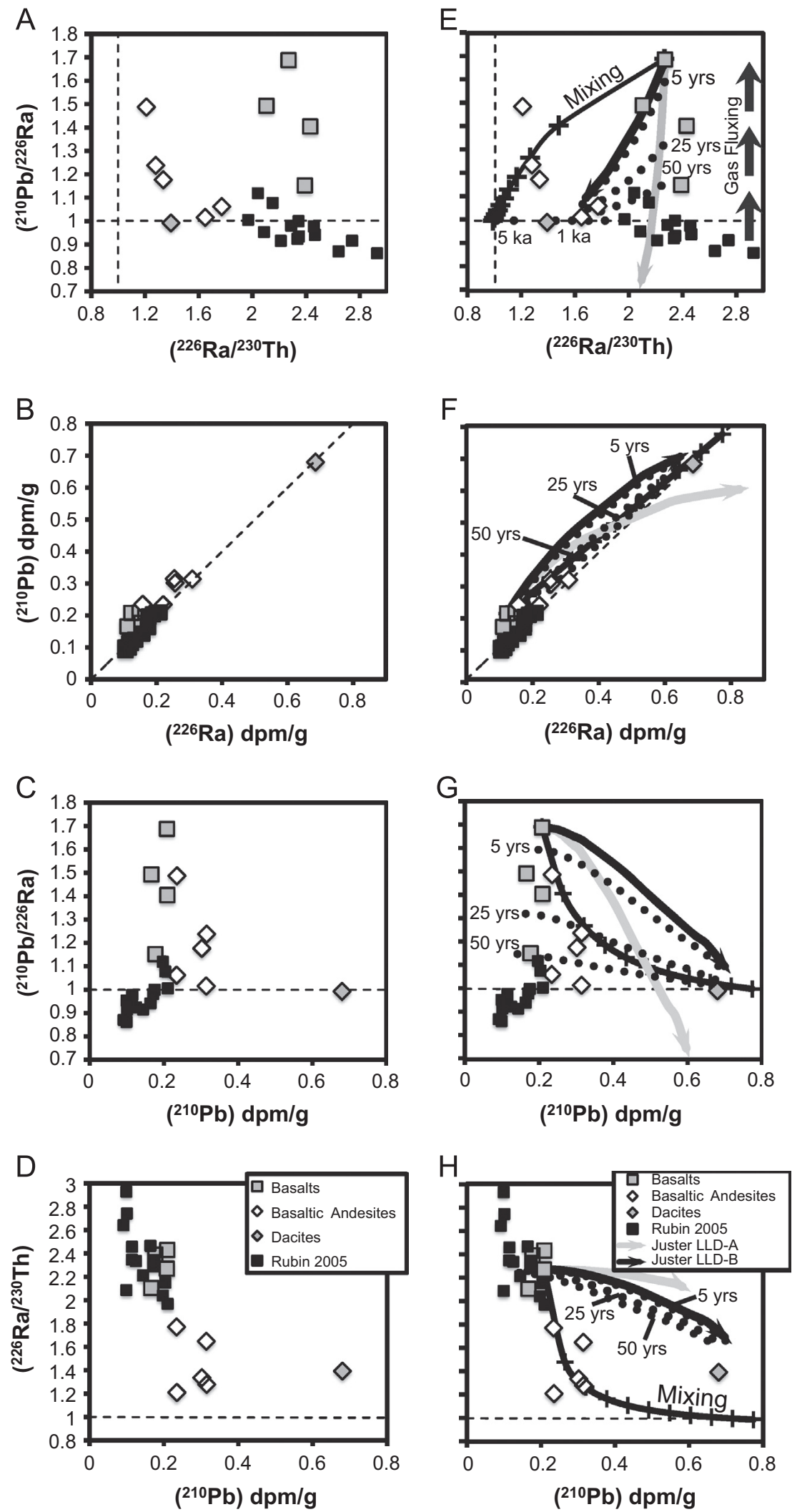

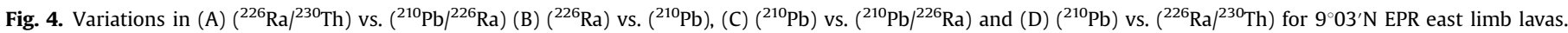

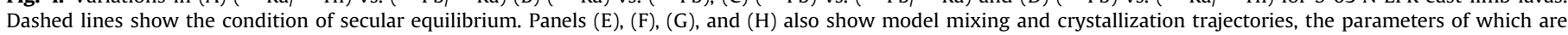

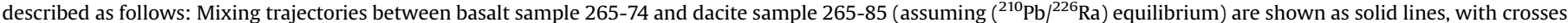

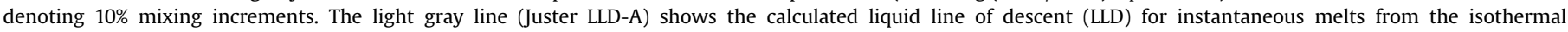

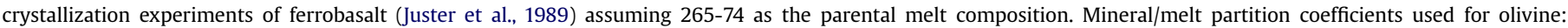

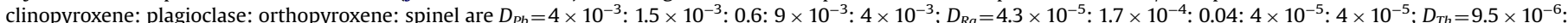

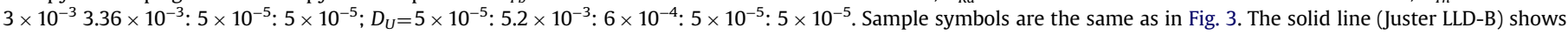

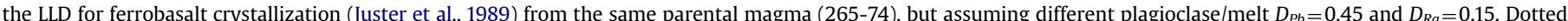

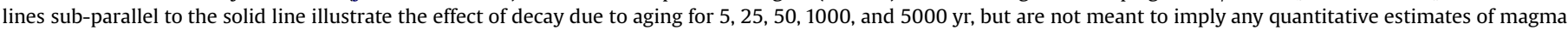

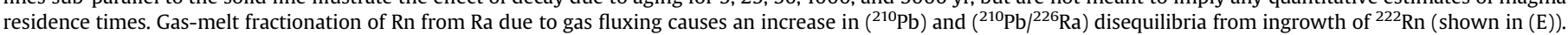
Crystallization, radioactive decay, and mixing with older magmas have the opposite effect. 
However, this melting scenario would be expected to result in correlations between geochemical indices of plagioclase or sulfide melting and $\left({ }^{210} \mathrm{~Pb} /{ }^{226} \mathrm{Ra}\right)$ disequilibria, which we do not observe in $9^{\circ} 03^{\prime} \mathrm{N}$ EPR lavas.

The origin of ${ }^{210} \mathrm{~Pb}$ excesses in arc lavas is thought to be caused by magma degassing, in which there is differential motion of gas relative to melt and subsequent accumulation of ${ }^{222} \mathrm{Rn}$-bearing gas (originating from deeper, degassing magma) in shallower magma bodies (e.g., Condomines et al., 2010; Cunningham et al., 2009; Kayzar et al., 2009; Reagan et al., 2006). Calculations using Stokes' Law indicate that gas bubbles will rise fast enough through basaltic magma, but not through more viscous dacitic magma, to cause differential motion of the gas and melt phases over the halflife of ${ }^{222}$ Rn (e.g., Kayzar et al., 2009). Berlo and Turner (2010) speculated that MORB lack ${ }^{210} \mathrm{~Pb}$ excesses (and thus evidence of gas-melt fractionation effects) either because they erupt effusively or have lower initial volatile concentrations. The presence of dacitic magmas at $9^{\circ} 03^{\prime} \mathrm{N}$ EPR may effectively serve as a viscosity barrier and facilitate the stalling and accumulation of rising gas. The association of more viscous, higher silica magmas with the magma chambers at $9^{\circ} 03^{\prime} \mathrm{N}$ EPR, Axial Seamount at Juan de Fuca (Chadwick et al., 2005), and in some arc settings may be the common factor needed to produce ${ }^{210} \mathrm{~Pb}$ excesses in MORB.

We envision a scenario (Fig. 5) in which a relatively large volume of basaltic magma residing within the lower to mid-crustal crystal mush zone or sills is continuously degassing. Radon-bearing $\mathrm{CO}_{2}-$ rich gas bubbles rise through the interstitial melt and accumulate beneath viscous dacite magma overlying the basalt and basaltic andesite magmas. ${ }^{222} \mathrm{Rn}$ accumulates and decays to ${ }^{210} \mathrm{~Pb}$ in a smaller volume of basaltic magma, producing ${ }^{210} \mathrm{~Pb}$ excesses in basaltic froth. Density instability due to accumulation of this buoyant bubble-rich basaltic magma froth beneath dacitic magma may facilitate magma mixing between basalt and dacite magma end members, which has been suggested to explain the wide range of intermediate compositions erupted at the $9^{\circ} 03^{\prime} \mathrm{N}$ OSC (Wanless et al., 2010).

In an effort to understand the observed correlations among U-series nuclides in $9^{\circ} 03^{\prime} \mathrm{N}$ east limb axial lavas, we estimated liquid lines of descent (LLD) for ferrobasaltic magmas using the experimental data of Juster et al. (1989). Mineral-melt partition coefficients were estimated from experimental data (Salters et al., 2002; Fabbrizio et al., 2009; Miller et al., 2007) and from theoretical considerations (Blundy and Wood, 2003). We calculated bulk partition coefficients assuming the mineral phase proportions reported for these experiments are the fractionating assemblages and equated melt fractions with experimental glass proportions. We estimated initial parent magma activities based on $U$ concentrations and U-series activity ratios from data for sample 265-74 (see Fig. 4 caption for details of the modeling parameters). Melt compositions for individual experiments were calculated using the formula for equilibrium crystallization. The results of these calculations, shown in Fig. 4E-H (curve labeled "Juster LLD-A") are both interesting and puzzling in that they hint at a possible role for fractional crystallization in producing the observed variations in $\left({ }^{210} \mathrm{~Pb}\right),\left({ }^{226} \mathrm{Ra}\right),\left({ }^{210} \mathrm{~Pb} /{ }^{226} \mathrm{Ra}\right)$, but not $\left({ }^{226} \mathrm{Ra} /{ }^{230} \mathrm{Th}\right)$ (Fig. 4D, H).

Given that the partition coefficients for $\mathrm{Pb}$ and $\mathrm{Ra}$ in plagioclase are not well constrained, particularly in the context of the extensive differentiation of tholeiitic magmas observed here and the relatively large range in plagioclase An content (cf., Blundy and Wood, 2003; Cooper et al., 2003; Fabbrizio et al., 2009), we also explore the effects of some variations in partition coefficients between melt and plagioclase for $\mathrm{Ra}$ and $\mathrm{Pb}$. In particular, we find that if $\mathrm{Pb}$ is slightly more incompatible $\left(D_{P b} \sim 0.4-0.5\right)$ and/or $\mathrm{Ra}$ is slightly more compatible $\left(D_{R a} \sim 0.10-0.20\right)$ in plagioclase than literature estimates $\left(D_{P b}>0.6, D_{R a} \sim 0.04\right)$, then the dacitic
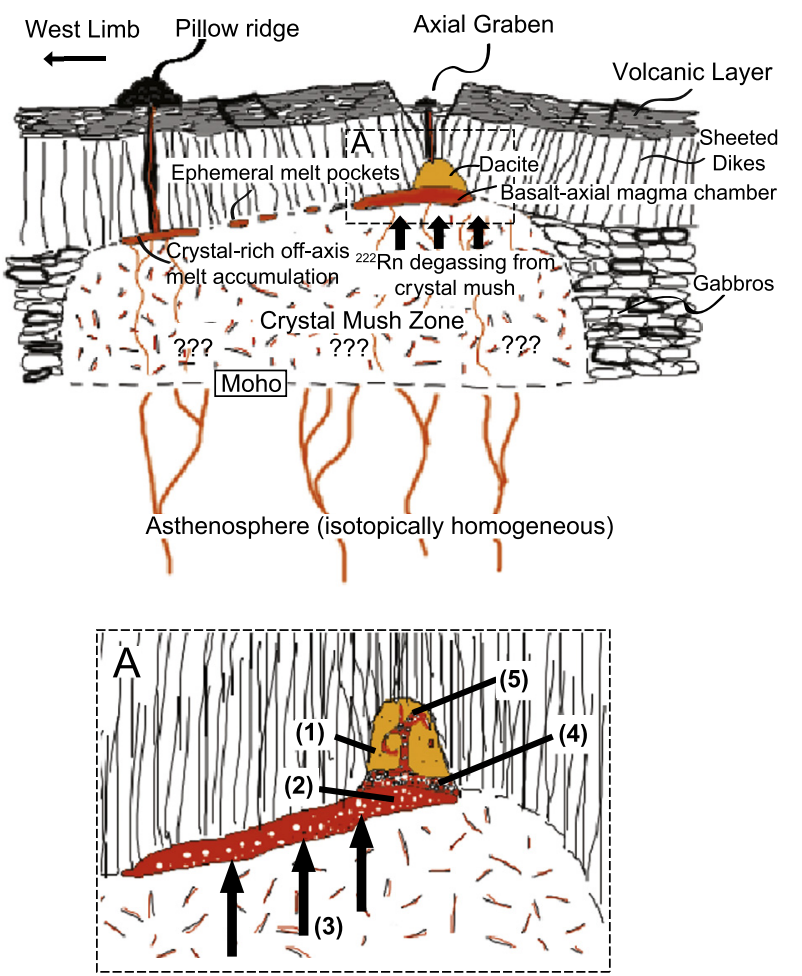

(1) dacite "cupola"

(2) basaltic magma sill

(3) ${ }^{222} \mathrm{Rn}$ degassing from plagioclase crystal mush

(4) bubble-rich basaltic froth-- ${ }^{210} \mathrm{~Pb}$ accumulation

(5) density instability and mixing of basalt froth and dacite

Fig. 5. Axis-perpendicular cartoon cross-section of the east limb of the $9^{\circ} 03^{\prime} \mathrm{N}$ OSC, illustrating how we envision the formation of ${ }^{210} \mathrm{~Pb}$ excesses in basalt beneath a dacite magma body and the eruption of an off-axis pillow ridge from an off-axis magma body. The inset illustration is an enlarged view of the subaxial magma bodies and corresponds to the dashed box above. The illustration is not to scale. In addition, though the illustration suggests the presence of a dacitic magma body overlying the sub-axial magma sill, the location of dacitic magma is not truly known. Detailed images and information on the seismically determined distribution and geometry of subsurface melt can be found in Kent et al. (2000) and Singh et al. (2006).

end member can be explained by a combination of fractional crystallization and prolonged residence times (Fig. 4, curve labeled "Juster LLD-B"). Subsequent mixing of basaltic and dacitic end members can then explain much of the compositional variability observed in intermediate lavas, as proposed by Wanless et al. (2010). Basaltic andesites with relatively low $\left({ }^{210} \mathrm{~Pb} /{ }^{226} \mathrm{Ra}\right)$ likely experienced post-eruptive aging either in the crust of on the seafloor without supporting gas accumulation.

This model illustrates that gas accumulation accompanied by fractional crystallization and magma mixing can explain many of the characteristics of this complicated magmatic system. If our model is correct, the presence of ${ }^{210} \mathrm{~Pb}$ disequilibria in both basaltic and basaltic andesite lavas attests to their short (decadal scale) magma residence times following gas accumulation in a magma chamber. In contrast, the fact that dacites that appear young have equilibrium $\left({ }^{210} \mathrm{~Pb} /{ }^{226} \mathrm{Ra}\right)$ and $\left({ }^{226} \mathrm{Ra} /{ }^{230} \mathrm{Th}\right)$, but $\left({ }^{230} \mathrm{Th} /{ }^{238} \mathrm{U}\right)$ similar to dacites and basaltic andesites with ${ }^{226} \mathrm{Ra}$ excesses (Fig. 3A) suggests that differentiation from basalt to dacitic compositions occurs on the order of $10 \mathrm{ka}$. This timeframe is long enough for both $\left({ }^{210} \mathrm{~Pb} /{ }^{226} \mathrm{Ra}\right)$ and $\left({ }^{226} \mathrm{Ra} /{ }^{230} \mathrm{Th}\right)$ to return to equilibrium, but short enough such that there is no measurable decrease in ${ }^{230} \mathrm{Th}$. This observation is roughly in agreement with estimates of basalt to dacite differentiation times of $10-20 \mathrm{ka}$ made by Schmitt et al. (2011) based on 
Table 2

${ }^{230} \mathrm{Th}-{ }^{226} \mathrm{Ra}$ model ages for east limb lavas.

\begin{tabular}{lllll}
\hline Sample & $\begin{array}{l}\text { Distance West from } \\
\text { Axial Graben Center } \\
(\mathrm{km})\end{array}$ & $\begin{array}{l}\text { Age based on } \\
\text { spreading rate } \\
(\mathrm{ka})\end{array}$ & $\begin{array}{l}\text { Age } \\
\text { limit } \\
(\mathrm{ka})\end{array}$ & $\begin{array}{l}{ }^{230} \mathrm{Th}^{226} \mathrm{Ra} \\
\text { model age }^{\mathrm{c}} \\
(\mathrm{ka})\end{array}$ \\
\hline $265-74$ & 0.1 & 1.0 & $<0.1$ & $0.1+0.3 /-0.1$ \\
$265-76$ & 0 & 0.8 & $<0.1$ & $0-0.1$ \\
$266-18$ & 0.3 & 6.2 & $<0.1$ & $0-0.2$ \\
$267-09$ & 0 & 1.1 & $<0.1$ & $0.4+0.3 /-0.4$ \\
$265-32$ & 1.7 & 31.4 & $<8$ & $0.7+0.3 /-0.5$ \\
$265-06$ & 3.7 & 67.9 & $<8$ & $1.1+0.3 /-0.5$ \\
$265-18$ & 3.1 & 55.7 & $<8$ & $0.9+0.3 /-0.5$ \\
$265-20$ & 3.1 & 56.6 & $<8$ & $1.0+0.3 /-0.5$ \\
$264-13$ & 0.1 & 2.4 & $<8$ & \\
$264-17$ & -0.1 & 1.5 & $<8$ & \\
$264-20$ & 0.1 & 2.1 & $<0.1$ & \\
$264-49$ & 0 & 0.2 & $<0.1$ & \\
$265-106$ & 0.1 & 1.0 & $<8$ & \\
$265-108$ & 0 & 1.3 & $<0.1$ & \\
$264-14$ & 0.1 & 1.0 & $<8$ & \\
$265-64$ & 0 & 0 & $<8$ & \\
$265-66$ & 0 & 0.2 & $<8$ & \\
\hline
\end{tabular}

${ }^{a}$ Distances estimated from the center of the axial graben assuming the neovolcanic axis is the spreading axis.

b Spreading ages were determined assuming a constant half-spreading rate of $5.5 \mathrm{~cm} / \mathrm{yr}$.

${ }^{c}$ Model ages were calculated using the equation from Sims et al. (2003) and assuming vertical decay from an initial zero-age $\left({ }^{226} \mathrm{Ra} /{ }^{230} \mathrm{Th}\right)$ at the sample $\left({ }^{230} \mathrm{Th} /{ }^{238} \mathrm{U}\right)$. The zero-age $\left({ }^{226} \mathrm{Ra} /{ }^{230} \mathrm{Th}\right)$ was calculated using the average of the four samples reported here with $\left({ }^{210} \mathrm{~Pb} /{ }^{226} \mathrm{Ra}\right)$ disequilibria, interpreted to be $<100 \mathrm{yr}$ old. Uncertainties reported for model ages incorporate both variability in initial $\left({ }^{226} \mathrm{Ra} /{ }^{230} \mathrm{Th}\right)$ disequilibria for $<100 \mathrm{yr}$ old lavas and analytical uncertainties. We do not calculate model ages for basaltic andesites or dacites (see text for details).

model U-Th differentiation ages. Due to their higher viscosity, slower bubble ascent rates, and longer residence times, dacitic magmas do not accumulate ${ }^{210} \mathrm{~Pb}$ from ${ }^{222} \mathrm{Rn}$ decay and $\left({ }^{210} \mathrm{~Pb} /{ }^{226} \mathrm{Ra}\right)$ returns to secular equilibrium.

\subsection{Lava eruption ages}

All samples have ${ }^{230} \mathrm{Th}$ excesses, indicating that they erupted $<375$ ka. Excluding dacite samples 265-83 and 265-85, which have $\left({ }^{226} \mathrm{Ra} /{ }^{230} \mathrm{Th}\right)$ of unity, all samples also have ${ }^{226} \mathrm{Ra}$ excesses. Thus, these samples erupted $<8 \mathrm{ka}$. In addition, ${ }^{226} \mathrm{Ra}$ excesses measured in axial basalts are similar to those of lavas erupted in 1991-92 at $9^{\circ} 50^{\prime} \mathrm{N}$ EPR (Fig. 3A), suggesting they are quite young. This is corroborated by ${ }^{210} \mathrm{~Pb}$ excesses in all measured axial basalts, which indicate that these samples are $<\sim 100 \mathrm{yr}$ old. Three axial basaltic andesites also have ${ }^{210} \mathrm{~Pb}$ excesses and were therefore also erupted $<100 \mathrm{yr}$ ago, and they are likely even much younger given the large magnitude of their ${ }^{210} \mathrm{~Pb}$ excesses. These age constraints are consistent with the sparse sediment cover and fresh appearance of sample glasses from axial lavas. Though interesting, the presence of recently erupted lavas within the axial graben is not a particularly surprising result given the fast spreading rate along the EPR. However, the ${ }^{226}$ Ra excesses of both off-axis flank and pillow ridge lavas is a more intriguing result, as these lavas were emplaced on crust with nominal spreading ages of $>50 \mathrm{ka}$ and are thus expected to have equilibrium $\left({ }^{226} \mathrm{Ra} /{ }^{230} \mathrm{Th}\right)$ (Fig. 3B). The fact that these lavas have ${ }^{226} \mathrm{Ra}$ excesses indicates that these lavas were emplaced off-axis.

We can use the ${ }^{230} \mathrm{Th}-{ }^{226} \mathrm{Ra}$ dating method of Sims et al. (2003) to calculate model ages for basalts (Fig. 1; Table 2) because both off-axis and axial basalts from $9^{\circ} 03^{\prime} \mathrm{N}$ EPR appear to share a common mantle source, are unaffected by secondary alteration, and most likely have short residence times ( $<100 \mathrm{yr}$; Rubin et al., 2005).
We further assume that initial ${ }^{230} \mathrm{Th}-{ }^{226} \mathrm{Ra}$ disequilibria is well represented by the four, $<100 \mathrm{yr}$ old axial basalts with ${ }^{210} \mathrm{~Pb}$ excesses. We do not report model ages for basaltic andesites or dacites. As discussed above, these samples have lower ${ }^{226} \mathrm{Ra}$ excesses indicating that they have either resided in crustal reservoirs for significant periods of time, relative to the half-life of ${ }^{226} \mathrm{Ra}$, or have experienced recharge and assimilation and thus are a mixture of melts with distinct ${ }^{238} \mathrm{U}-{ }^{230} \mathrm{Th}-{ }^{226} \mathrm{Ra}$ isotopic compositions, rendering their model ages invalid.

The ${ }^{230} \mathrm{Th}-{ }^{226} \mathrm{Ra}$ model ages for basalts show that the pillow ridge and seamount basalt samples 265-18, 265-20, and 265-06 all have model ages of $\sim 1.0 \mathrm{ka}$ (Fig. 1, Table 2 ). The flank basalt sample $265-32$ is slightly younger at $0.7 \mathrm{ka}$. These off-axis lavas are older than axial lavas. These model age relationships are consistent with photographic and hand sample observations (Fig. 2).

\subsection{Linking sill to surface off-axis at the $9^{\circ} 03^{\prime} \mathrm{N}$ OSC}

A preponderance of evidence points to a scenario in which the magma that erupted to form the young off-axis pillow ridge and seamount was supplied from the underlying off-axis portion of the wide melt lens (Fig. 5):

(1) Bathymetry and side scan sonar (White et al., 2009) imaging show that the studied volcanic pillow ridge and seamount are off-axis eruptive features, and not connected via a surface or channelized flow to the spreading axis.

(2) U-series age limits indicate that these samples erupted $<8 \mathrm{ka}$, and $\mathrm{U}$-series model ages suggest that these lavas are much younger ( $\sim 1 \mathrm{ka})$. These young ages necessitate that these lavas erupted on crust directly over the seismically imaged off-axis melt body.

(3) Petrologic observations suggest the crustal magma source for pillow ridge basalts is not in direct communication with the crustal magma source for axial lavas. Namely, only basalts have erupted off-axis, whereas lavas erupted within the axial graben range from basalt to dacite, demonstrating that the formation and storage of high-silica lavas occurs solely under the ridge axis (Wanless et al., 2010). In addition, pillow ridge lavas have more primitive compositions and are more crystal-rich than axial basalts (Klein et al., 2007; Zaino et al., 2008). We cannot rule out the possibility that the off-axis melt that underlies the pillow ridge is in fact the cooler, more crystalline western part of one large melt sill distorted by the overlapping spreading centers, or that the sub-axial melt sill had different properties when the pillow ridge basalts erupted $\sim 1 \mathrm{ka}$. In either case, the more recently erupted axial basalts likely experienced greater extents of crystallization and more efficient melt-crystal segregation while residing in a melt-rich magma sill directly beneath the axial graben, whereas the more primitive, crystal-rich compositions of off-axis pillow ridge basalts suggest that they come from a smaller, relatively melt-poor/crystal-rich and potentially ephemeral magma body such as that imaged below them. Similar petrologic arguments have been used to argue that the crustal magma source for off-axis volcanism along the EPR is different from the source for axial lavas (Batiza and Vanko, 1984; Geshi et al., 2007). In addition, the $\mathrm{Sr}$ and $\mathrm{Nd}$ isotopic uniformity implies a similar mantle source for both off-axis and axial lavas, and thus petrologic differences are due largely to crustal magmatic processes.

(4) The off-axis pillow ridge and seamount are aligned parallel to the spreading axis, further suggesting that distributed extensional stresses, which can easily accommodate vertical diking, are responsible for this off-axis volcanism, as expected based on the plate unbending model of Sohn and Sims (2005). Vertical diking from the western extent of the off-axis melt lens can explain the petrologic character of the off-axis lavas, as it would deliver 
primitive, crystal-rich magmas to the seafloor from a mid-crustal mush zone.

Thus, although none of these lines of evidence constitutes a 'smoking gun' by itself and more convoluted magmatic-volcanic linkages are possible, we believe that the simplest, and therefore most likely, explanation for these observations is that the off-axis volcanic activity was sourced directly from the underlying, off-axis magma body, as is envisioned in Fig. 5.

\subsection{Implications for off-axis magmatism and volcanism}

Studies of off-axis volcanism along the EPR have long used petrology and geochemistry to speculate on the magmatic source for off-axis volcanism and its relationship to axial volcanism and magmatism (e.g., Geshi et al., 2007; Hall and Sinton, 1996; Perfit et al., 1994; Reynolds et al., 1992). Likewise, geophysical studies have provided evidence for the presence of off-axis melt bodies (e.g., Canales et al., 2009, 2012; Durant and Toomey, 2009), but until the AT15-17 survey (see also Wanless et al., 2012), it has not been possible to directly link lava age, geochemistry, and petrology with seafloor and seismic imaging, since such a broad range of multidisciplinary data are only rarely collectively available in submarine settings. At the most fundamental level, this connection between off-axis magmatism and volcanism demonstrates that off-axis volcanism can be sourced from off-axis magma bodies at certain tectonic settings (cf., Sohn and Sims, 2005). In turn, geophysical surveys may be able to confirm the presence of postulated off-axis magma bodies where petrologic study has suggested their existence (e.g., $8^{\circ}$ S EPR, $14^{\circ}$ S EPR; cf., Geshi et al., 2007; Hall and Sinton, 1996).

Furthermore, this connection between off-axis volcanism and a deeper crustal magma source at $9^{\circ} 03^{\prime} \mathrm{N}$ EPR begs for additional geochemical and petrologic investigation of these off-axis lavas, as they may provide a window into how magma evolves as it is transported and stored at different depths and conditions within the oceanic crust. For example, one explanation for isotopically homogeneous lavas in a region of small-scale isotopic mantle heterogeneity (Waters et al., 2011) is that magma mixing and homogenization may occur deeper in the crust (perhaps even during melt extraction in the mantle) than the sub-axial magma sill, either laterally or along-axis. Additional study of volatile element equilibration pressures of olivine hosted melt inclusions (cf. Wanless and Shaw, 2012) in axial vs. off-axis basalts might better constrain the different depths from which these lavas originated and homogenized. In addition, the observation of lower initial $\left({ }^{226} \mathrm{Ra} /{ }^{230} \mathrm{Th}\right)$ disequilibria at a given $\left({ }^{230} \mathrm{Th} /{ }^{238} \mathrm{U}\right)$ upon eruption in axial basalts from $9^{\circ} 03^{\prime} \mathrm{N}$ EPR compared with basalts from $9^{\circ} 50^{\prime} \mathrm{N}$ EPR suggests some combination of small differences in mantle melting and longer magma residence times beneath the OSC prior to ${ }^{222} \mathrm{Rn}$ accumulation and development of ${ }^{210} \mathrm{~Pb}$ excesses (up to $\sim 1 \mathrm{ka}$ ).

\section{Conclusions}

We measured ${ }^{87} \mathrm{Sr} /{ }^{86} \mathrm{Sr},{ }^{143} \mathrm{Nd} /{ }^{144} \mathrm{Nd}$, and ${ }^{238} \mathrm{U}-{ }^{230} \mathrm{Th}-{ }^{226} \mathrm{Ra}-{ }^{210} \mathrm{~Pb}$ isotope compositions for a suite of axial and off-axis lavas from the $9^{\circ} 03^{\prime} \mathrm{N}$ OSC along the East Pacific Rise. Our results provide insight into the nature and time scales of both axial and off-axis magmatism and volcanism at a fast-spreading ridge segment. Firstly, the most recent volcanism along the eastern limb of the overlapping spreading center at $9^{\circ} 03^{\prime} \mathrm{N}$ East Pacific Rise occurs within the axial graben. The presence of $\left({ }^{210} \mathrm{~Pb} /{ }^{226} \mathrm{Ra}\right)$ disequilibria indicates that both basalt and basaltic andesite lavas have erupted within the past $\sim 100 \mathrm{yr}$. More evolved dacites have equilibrium $\left({ }^{226} \mathrm{Ra} /{ }^{230} \mathrm{Th}\right)$ and $\left({ }^{210} \mathrm{~Pb} /{ }^{226} \mathrm{Ra}\right)$, indicating either that the residence times of dacite magmas are on the order of $\sim 10 \mathrm{ka}$, and/or that younger, less evolved magmas have mixed with older magmas. Secondly, we posit that ${ }^{210} \mathrm{~Pb}$ excesses in basalt and basaltic andesite lavas from $9^{\circ} 03^{\prime} \mathrm{N}$ EPR were generated by gas-melt fractionation processes and that ${ }^{222} \mathrm{Rn}$ accumulation occurred because the presence of viscous dacitic magma overlying basaltic magma impeded Rn-bearing gas bubble ascent. Magma mixing between old, degassed, dacitic magma and young, undegassed, basaltic magma generated intermediate magma compositions. Finally, lavas from the off-axis pillow ridge and seamount overlying the western extent of the seismically imaged melt sill erupted $\sim 1$ ka on crust with a nominal spreading age of $>50 \mathrm{ka}$, demonstrating that these lavas erupted in place. Geological, petrologic, age, and seismic evidence support a scenario in which the off-axis pillow ridge and seamount were sourced from the seismically imaged magma body underlying these volcanic features.

\section{Acknowledgments}

This manuscript benefited from discussions with M. Tivey, A. Soule, G. Gaetani, D. Wanless, and A. Nunnery, from reviews by K. Rubin, O. Sigmarsson, and editor T. Elliot, and from reviews on a previous version by K. Rubin, S. Umino, and W. Collins. J. Inglis and E. Baxter helped with TIMS Sr isotope analyses at Boston University. J. Blusztajn provided laboratory and analytical assistance at WHOI. Seagoing efforts of the scientific staff and the crew of the R/V Atlantis on "MEDUSA" cruise AT15-17 made this work possible. This study was funded by NSF grants OCE-0527053 and OCE-0623838 to K.W.W.S., OCE-0525872 to S.M.W., OCE-0526120 to E.M.K, and EAR-0738776 to M.K.R.

\section{Appendix A. Methods for ${ }^{210} \mathrm{~Pb}$ analysis}

Activities of ${ }^{210} \mathrm{~Pb}\left(t_{1 / 2}=22.6 \mathrm{yr}\right)$ were obtained by measuring activities of its daughter ${ }^{210} \mathrm{Po}\left(t_{1 / 2}=138.4\right.$ days $)$ by alpha spectrometry at the University of Iowa using methods outlined in Reagan et al. (2005) and Reagan et al. (2006), and assuming secular equilibrium [i.e., $\left.\left({ }^{210} \mathrm{Po}\right) /\left({ }^{210} \mathrm{~Pb}\right)=1\right]$, which is a valid assumption given that the analyses were conducted in April 2011, 4 yr after the samples were collected. Three grams of sample powders are weighed for analysis and are spiked with a ${ }^{209} \mathrm{Po}$ standard solution calibrated against a $\left({ }^{210} \mathrm{Po}\right)$ value of $7.95 \mathrm{dpm} / \mathrm{g}$ for TML (Table Mountain Latite). USGS rock standards BCR-2 (2 g) and RGM-2 (1 g) are frequently run to monitor the spike calibration. The samples are digested in a $\mathrm{HF}-\mathrm{HNO}_{3}$ mixture. Polonium is separated using anion exchange chromatography. The purified Po is autoplated on $\mathrm{Ag}$ disks in $100 \mathrm{~mL}$ of warm $0.5 \mathrm{~N} \mathrm{HCl}$ containing approximately $100 \mathrm{mg}$ of ascorbic acid. The detectors used in this study (EGG Ortec alpha spectrometry system) were of the see-noalpha type when purchased and most have been used only for counting ${ }^{210} \mathrm{Po}$ (two of the detectors have been rarely used for counting Th isotopes). We measure single, long counts of $\sim 1$ million seconds for each of the samples. Counts are corrected for backgrounds, blanks, the small tail of the ${ }^{210}$ Po peak under the ${ }^{209}$ Po peak $(<0.1 \%$ for these samples), and decay of ${ }^{210} \mathrm{Po}$ after running the column that separated it from ${ }^{210} \mathrm{~Pb}$. Sample backgrounds are very low (0.0002 to $0.002 \mathrm{dpm}$, which correspond to $<1 \%$ of the total counts for all samples) and stable. The blank correction for ${ }^{210}$ Po was less than $1 \%$ for all samples.

$\left({ }^{210} \mathrm{Po}\right)$ values for two separate runs of USGS standard BCR-2 measured at the same time as the EPR samples were $1.276 \pm 0.056$ and $1.264 \pm 0.046 \mathrm{dpm} / \mathrm{g}(2 \sigma)$ for $0.9 \mathrm{~g}$ and $1.6 \mathrm{~g}$ of powder, respectively. The accepted ( $\left.{ }^{210} \mathrm{Po}\right)$ value for BCR-2 is $1.26 \mathrm{dpm} / \mathrm{g}$ based on $\mathrm{U}$ concentrations from Sims et al. (2008b) and the assumption of equilibrium. Typical EPR basalts analyzed in this study have similar analytical precision (3.8-5.6\%) to BCR-2 (4.4\% and 3.6\%) 
due to the larger, $3 \mathrm{~g}$ sample sizes used for MORB [e.g., our lowest activity sample $267-09$ gives $\left({ }^{210} \mathrm{Po}\right)=0.166 \pm 0.009 \mathrm{dpm} / \mathrm{g}(2 \sigma)$, or $\pm 4.8 \%$ RSD $(2 \sigma)]$. East Pacific Rise samples generally had lower overall counts of ${ }^{210} \mathrm{Po}$, but ${ }^{209} \mathrm{Po}$ spike counts were similar for the samples and standards. Estimates of measurement analytical uncertainty (see Table 1) include propagated uncertainties of the spike, tail correction, background, blank, and counting statistics. Although the samples analyzed in this study have $1 / 8$ to $1 / 2$ the activity of BCR-2, the alpha spectrometers are expected to have a linear response at the very low count rates for ${ }^{209} \mathrm{Po}$ and ${ }^{210} \mathrm{Po}$ for either the samples or standards (e.g., the dead-time correction is trivial). The ability to accurately analyze samples with low $\left({ }^{210} \mathrm{Po}\right)$ is demonstrated in Reagan et al. (2005) (three samples were between $0.130-0.175 \mathrm{dpm} / \mathrm{g}$ ) and Reagan et al. (2006) (0.029$0.460 \mathrm{dpm} / \mathrm{g}$ ), both of which include values comparable to the activities reported in this study $(0.166-0.680 \mathrm{dpm} / \mathrm{g})$. In particular Reagan et al. (2006) measured a time-series of ingrowing $\left({ }^{210} \mathrm{Po}\right)$ in the whole rock $(0.037-0.347 \mathrm{dpm} / \mathrm{g})$, groundmass $(0.044-$ $0.460 \mathrm{dpm} / \mathrm{g})$, and fine $(0.045-0.068 \mathrm{dpm} / \mathrm{g})$ and coarse $(0.029$ $0.037 \mathrm{dpm} / \mathrm{g}$ ) plagioclase separates of a sample from the July 13 , 2003 eruption at Arenal volcano, Costa Rica, beginning 12 days after the eruption. Exponential regression of these time-series analyses constrained by the half-life for ${ }^{210}$ Po further attest to our ability to measure $\left({ }^{210} \mathrm{Po}\right)$ both accurately and precisely in samples with $\left({ }^{210} \mathrm{Po}\right)$ both less than and similar to our EPR samples (cf. Fig. 2 of Reagan et al., 2006).

\section{Appendix B. Supporting information}

Supplementary data associated with this article can be found in the online version at http://dx.doi.org/10.1016/j.epsl.2013.03.006.

\section{References}

Batiza, R., Vanko, D., 1984. Petrology of young Pacific seamounts. J. Geophys. Res. 89 (B13), 11235-11260.

Bazin, S., Harding AJ, Kent, G.M. Orcutt, J.A Singh, S.C. Tong C.H., Pye, J.W Barton, P.J., Sinha, M.C., White, R.S., Hobbs, R.W., Van Avendonk, H.J.A., 2003. A three-dimensional study of a crustal low velocity region beneath the $9^{\circ} 03^{\prime} \mathrm{N}$ overlapping spreading center. Geophys. Res. Lett. 30 (2), 1-4, http://dx.doi.org/ 10.1029/2002GL015137.

Bergmanis, E.C., Sinton, J., Rubin, K.H., 2007. Recent eruptive history and magma reservoir dynamics on the southern East Pacific Rise at $17^{\circ} 30^{\prime} \mathrm{S}$. Geochem. Geophys. Geosyst. 8 (12), http://dx.doi.org/10.1029/2007GC001742.

Berlo, K., Turner, S., Blundy, J., Black, S., Hawkesworth, C., 2006. Tracing pre-eruptive magma degassing using $\left({ }^{210} \mathrm{~Pb} /{ }^{226} \mathrm{Ra}\right)$ disequilibria in the volcanic deposits of the 1980-1986 eruption of Mount St. Helens. Earth Planet. Sci. Lett 249, 337-349.

Berlo, K., Turner, S., 2010. ${ }^{210} \mathrm{~Pb}-{ }^{226} \mathrm{Ra}$ disequilibria in volcanic rocks. Earth Planet. Sci. Lett. 296, 155-164.

Blundy, J., Wood, B., 2003. Mineral-melt partitioning of uranium, thorium and their daughters. Rev. Mineral. Geochem. 52, 59-123.

Canales, J.P., Nedmovic, M.R., Kent, G.M., Carbotte, S.M., Detrick, R.S., 2009. Seismic reflection images of a near-axis melt sill within the lower crust at the Juan de Fuca ridge. Nature 460, 89-94, http://dx.doi.org/10.1038/nature08095.

Canales, J.P., Carton, H., Carbotte, S.M., Mutter, J.C., Nedmovic, M.R., Xu, M., Aghaei, O., Marjanovic, M., Newman, K., 2012. Network of off-axis melt bodies at the East Pacific Rise. Nat. Geosci. , http://dx.doi.org/10.1038/NGEO1377.

Carmichael, I.S.E., 1964. The petrology of Thingmuli, a Tertiary volcano in eastern Iceland. J. Petrol. 5 (3), 435-460.

Chadwick, J., Perfit, M., Ridley, I., Jonasson, I., Kamenov, G., Chadwick, W., Embley, R., Le Roux, P., Smith, M., 2005. Magmatic effects of the Cobb hot spot on the Juan de Fuca Ridge. J. Geophys. Res. 110 (B03101), http://dx.doi.org/10.1029/ 2003JB002767.

Combier, V., Singh, S.C., Cannat, M., Escartin, J., 2008. Mechanical decoupling and thermal structure at the East Pacific Rise axis $9^{\circ} \mathrm{N}$ : constraints from axia magma chamber geometry and seafloor structures. Earth Planet. Sci. Lett. 272, 19-28.

Condomines, M., Sigmarsson, O., Gauthier, P.J., 2010. A simple model of ${ }^{222} \mathrm{Rn}$ accumulation leading to ${ }^{210} \mathrm{~Pb}$ excesses in volcanic rocks. Earth Planet. Sci. Lett. 293, 331-338.

Cooper, K.M., Goldstein, S.J., Sims, K.W.W., Murrell, M.T., 2003. Uranium-series chronology of Gorda Ridge volcanism: new evidence from the 1996 eruption. Earth Planet. Sci. Lett. 206, 459-475.
Crawford, W.C., Webb, E.S., 2002. Variations in the distribution of magma in the lower crust and at the Moho beneath the East Pacific Rise at $9^{\circ}-10^{\circ} \mathrm{N}$. Earth Planet. Sci. Lett. 203, 117-130.

Cunningham, H.S., Turner, S.P., Patia, H., Wysoczanski, R., Nichols, A.R.L., Eggins, S., Dosseto, A., 2009. ${ }^{210} \mathrm{~Pb} /{ }^{226} \mathrm{Ra}$ ) variations during the $1994-2001$ intracaldera volcanism at Rabaul Caldera. J. Volcanol. Geotherm. Res. 184, 416-426.

Dreyer, B., Clague, D.A., Gill, J.B., 2009. Magmagenesis at Axial Seamount, Juan de Fuca Ridge: insights from Uranium-series systematics. Eos Trans. AGU 90 (52), Fall Meeting Suppl., V51D-1735.

Dunn, R., Toomey, D., Solomon, S., 2000. Three-dimensional seismic structure and physical properties of the crust and shallow mantle beneath the East Pacific Rise. J. Geophys. Res. 105, 23537-23555.

Durant, D.T., Toomey, D.R., 2009. Evidence and implications of crustal magmatism on the flanks of the East Pacific Rise. Earth Planet. Sci. Lett. 287, 130-136.

Elkins, L.J., Sims, K.W.W., Prytulak, J., Elliot, T., Mattielli, N., Blichert-Toft, J., Blusztajn, J., Dunbar, N., Devey, C., Mertz, D.F., Schilling, J.-G., Murrell, M., 2011. Understanding melt generation beneath the slow-spreading Kolbeinsey Ridge using ${ }^{238} \mathrm{U},{ }^{230} \mathrm{Th}$, and ${ }^{231} \mathrm{~Pa}$ excesses. Geochim. Cosmochim. Acta 75 , 6300-6329.

Fabbrizio, A., Schmidt, M.W., Gunther, D., Eikenberg, J., 2009. Experimental determination of Ra mineral/melt partitioning for feldspars and equilibrium crystallization ages of plagioclase and alkali-feldspar. Earth Planet. Sci. Lett. 280, 137-148.

Geshi, N., Umino, S., Kumagai, H., Sinton, J.M., White, S.M., Kiyoyuki, K., Hilde, T.W., 2007. Discrete plumbing systems and heterogeneous magma sources of a $24 \mathrm{~km}^{3}$ off-axis lava field on the western flank of East Pacific Rise, $14^{\circ} \mathrm{S}$. Earth Planet. Sci. Lett. 258, 61-72.

Goldstein, S.J., Perfit, M.R., Batiza, R., Fornari, D.J., Murrell, M.T., 1994. Off-axis volcanism at the East Pacific Rise detected by uranium-series dating of basalts. Nature 367, 157-159.

Goss, A.R., Perfit, M.R., Ridley, W.I., Rubin, K.H., Kamenov, G.D., Soule, S.A., Fundis, A., Fornari, D.J., 2010. Geochemistry of lavas from the 2005-2006 eruption at the East Pacific Rise, $9^{\circ} 46^{\prime} \mathrm{N}-9^{\circ} 56^{\prime} \mathrm{N}$ : implications for ridge crest plumbing and decadal changes in magma chamber composition. Geochem. Geophys., Geosyst. 11 (5), http://dx.doi.org/10.1029/2009GC002977.

Hall, L., Sinton, J., 1996. Geochemical diversity of the large lava field on the flank of the East Pacific Rise at $8^{\circ} 17^{\prime}$ S. Earth Planet. Sci. Lett. 142, 241-251.

Juster, T.C., Grove, T.L., Perfit, M.R., 1989. Experimental constraints on the generation of FeTi basalts, andesites, and rhyodacites at the Galapagos Spreading Center, $85^{\circ} \mathrm{W}$ and $95^{\circ} \mathrm{W}$. J. Geophys. Res. 94 (B7), 9251-9274.

Kayzar, T.M., Cooper, K.M., Reagan, M.K., Kent, A.J.R., 2009. Gas transport model for the magmatic system at Mount Pinatubo, Philippines: insights from $\left({ }^{210} \mathrm{~Pb}\right) /$ $\left({ }^{226} \mathrm{Ra}\right)$. J. Volcan. Geotherm. Res. 181, 124-140.

Kent, G.M., Singh, S., Harding, A., Sinha, M., Orcutt, J., Barton, P., Bazin, S., Hobbs, R., Tong, C., Pye, J., 2000. Evidence from three-dimensional seismic reflectivity images for enhanced melt supply beneath mid-ocean ridge discontinuitie. Nature 406, 614-618.

Klein, E.M., et al., 2007. Detailed investigation of the overlapping spreading center and $9^{\circ} \mathrm{N}$ on the East Pacific Rise: overview of the Medusa 2007 cruise activities. Eos Trans. AGU 88 (52), Fall Meet. Suppl., T32B-03.

Lundstrom, C.C., Gill, J., Williams, Q., Perfit, M.R., 1995. Mantle melting and basalt extraction by equilibrium porous flow. Science 270 (5244), 1958-1961.

Miller, S.A., Burnett, D.S., Asimow, P.D., Phinney, D.L., Hutcheon, I.D., 2007. Experimental study of radium partitioning between anorthite and melt at 1 atm. Am. Mineral. 92, 1535-1538.

Perfit, M.R., Fornari, D.J., Smith, M.C., Bender, J.F., Langmuir, C.H., Haymon, R.M., 1994. Small-scale spatial and temporal variations in mid-ocean ridge crest magmatic processes. Geology 22, 375-379.

Reagan, M., Tepley III, F.J., Gill, J.B., Wortel, M., Hartman, B., 2005. Rapid time scales of basalt to andesite differentiation at Anatahan volcano, Mariana Island. J. Volcanol. Geotherm. Res. 146, 171-183, http://dx.doi.org/10.1016/j.jvolgeores.2004.10.022.

Reagan, M.K., Tepley III, F.J., Gill, J.B., Wortel, M., Garrison, J., 2006. Timescales of degassing and crystallization implied by ${ }^{210} \mathrm{Po}-{ }^{210} \mathrm{~Pb}-{ }^{226} \mathrm{Ra}$ disequilibria for andesitic lavas erupted from Arenal volcano. J. Volcanol. Geotherm. Res. 157, 135-146.

Reynolds, J.R., Langmuir, C.H., Bender, J.F., Kastens, K.A., Ryan, W.B.F., 1992. Spatial and temporal variability in the geochemistry of basalts from the East Pacific Rise. Nature 359, 493-499.

Richter, S., Goldberg, S.A., 2003. Improved techniques for high accuracy isotope ratio measurements of nuclear materials using thermal ionization mass spectrometry:. Int. J. Mass Spectrom. 229, 181-197.

Rubin, K.H., MacDougall, J.D., 1990. Dating of neovolcanic MORB using $\left({ }^{226} \mathrm{Ra} /{ }^{230} \mathrm{Th}\right)$ disequilibrium. Earth Planet. Sci. Lett. 101, 313-321.

Rubin, K.H., van der Zander, I., Smith, M.C., Bergmanis, E.C., 2005. Minimum speed limit for ocean ridge magmatism from ${ }^{210} \mathrm{~Pb}-{ }^{226} \mathrm{Ra}-{ }^{230} \mathrm{Th}$ disequilibria. Nature 437, 534-538.

Salters, V.J.M., Longhi, J.E., Bizimis, M., 2002. Near mantle solidus trace element partitioning at pressures up to $3.4 \mathrm{GPa}$. Geochem. Geophys. Geosyst. 3 (7).

Schmitt, A.K., Perfit, M.R., Rubin, K.H., Stockli, D.F., Smith, M.C., Cotsonika, L.A., Zellmer, G.F., Ridley, W.I., Lovera, O.M., 2011. Rapid cooling rates at an active mid-ocean ridge from zircon thermochronology. Earth Planet. Sci. Lett. 302, 349-358.

Sims, K.W.W., Goldstein, S.J., Blichert-Toft, J., Perfit, M.R., Kelemen, P., Fornari, D.J., Michael, P., Murrell, M.T., Hart, S.R., DePaolo, D.J., Layne, G., Jull, M., 2002. Chemical and isotopic constraints on the generation and transport of melt beneath the East Pacific Rise. Geochim. Cosmochim. Acta 66, 3481-3504. 
Sims, K.W.W., Blichert-Toft, J., Fornari, D.J., Perfit, M.R., Goldstein, S.J., Johnson, P., DePaolo, D.J., Hart, S.R., Murrell, M.T., Michael, P.J., Layne, G.D., Ball, L., 2003. Aberrant youth: chemical and isotopic constraints on the origin of off-axis lavas from the East Pacific Rise, $9^{\circ}-10^{\circ}$ N. Geochem. Geophys. Geosyst. 4 (10), http: //dx.doi.org/10.1029/2002GC000443.

Sims, K.W.W., Gill, J.B., Dosseto, A., Hoffmann, D.L., Lundstrom, C.C., Williams, R.W., Ball, L., Tollstrup, D., Turner, S., Prytulak, J., Glessner, J.J.G., Standish, J.J., Elliott, T., 2008a. An inter-laboratory assessment of the thorium isotopic composition of synthetic and rock reference materials. Geostand. Geoanal. Res. 32, 65-91.

Sims, K.W.W., Hart, S.R., Reagan, M.K., Blusztajn, J., Staudigel, H., Sohn, R.A., Layne, G.D., Ball, L.A., Andrews, J., 2008b. ${ }^{238} \mathrm{U}-{ }^{230} \mathrm{Th}-{ }^{226} \mathrm{Ra}-{ }^{210} \mathrm{~Pb}-{ }^{210} \mathrm{Po},{ }^{232} \mathrm{Th}-{ }^{226} \mathrm{Ra}$, and ${ }^{235} \mathrm{U}-{ }^{231} \mathrm{~Pa}$ constraints on the ages and petrogenesis of Vailulu'u and Malumalu Lavas, Samoa. Geochem. Geophys. Geosyst. 9 (4), http://dx.doi.org/ 10.1029/2007GC001651.

Singh, S., Harding, A., Kent, G., Sinha, M., Combier, V., Bazin, S., Tong, C., Pye, J., Barton, P., Hobbs, R., White, R., Orcutt, J., 2006. Seismic reflection images of the moho underlying melt sills at the East Pacific Rise. Nature 442, 287-290.

Sinton, J.M., Detrick, R.S., 1992. Mid-Ocean Ridge Magma Chambers. J. Geophys. Res. 97 (B1), 197-216.

Sohn, R.A., Sims, K.W.W., 2005. Bending as a mechanism for triggering off-axis volcanism on the East Pacific Rise. Geology 33 (2), 93-96, http://dx.doi.org/ 10.1130/G21116.1.

Thurber, D., 1962. Anomalous ${ }^{234} U /{ }^{238} U$ in nature. J. Geophys. Res. 67, 4518.

Toomey, D.R., Jousselin, D., Dunn, R.A., Wilcock, W., Detrick, R.S., 2007. Skew of mantle upwelling beneath the East Pacific Rise governs segmentation. Nature, 446, http://dx.doi.org/10.1038/nature05679.

Turner, S., Black, S., Berlo, K., 2004. ${ }^{210} \mathrm{~Pb}-{ }^{226} \mathrm{Ra}$ and ${ }^{228} \mathrm{Ra}-{ }^{232} \mathrm{Th}$ systematics in young arc lavas: implications for magma degassing and ascent rates. Earth Planet. Sci. Lett. 227, 1-16.

Van Orman, J.A., Saal, A.E., 2009. Influence of crustal cumulates on ${ }^{210} \mathrm{~Pb}$ disequilibria in basalts. Earth Planet. Sci. Lett. 284, 284-291, http://dx.doi.org/10.1016/j. epsl.2009.04.034.
Wanless, V.D., Perfit, M.R., Ridley, W.I., Klein, E., 2010. Dacite petrogenesis on midocean ridges: evidence for oceanic crustal melting and assimilation. J. Petrol. 51 (12), 2377-2410, http://dx.doi.org/10.1093/petrology/egq056.

Wanless, V.D., Perfit, M.R., Ridley, W.I., Wallace, P.J., Grimes, C.B., Klein, E.M., 2011 Volatile abundances and oxygen isotopes in basaltic to dacitic lavas on midocean ridges: the role of assimilation at spreading centers. Chem. Geol. 287, 54-65.

Wanless, V.D., Perfit, M.R., Klein, E.M., White, S., Ridley, W.I., 2012. Reconciling geochemical and geophysical observations of magma supply and melt distribution at the $9^{\circ} \mathrm{N}$ overlapping spreading center, East Pacific Rise. Geochem. Geophys. Geosyst., 13, http://dx.doi.org/10.1029/2012GC004168.

Wanless, V.D., Shaw, A.M., 2012. Lower crustal crystallization and melt evolution at mid-ocean ridges. Nat. Geosci. 5, 651-655, http://dx.doi.org/10.1038/ NGEO1552.

Waters, C.L., Sims, K.W.W., Perfit, M.R., Blichert-Toft, J., Blusztajn, J., 2011. Perspective on the genesis of E-MORB from chemical and isotopic heterogeneity at $9^{\circ}-$ $10^{\circ} \mathrm{N}$ East Pacific Rise. J. Petrol. 52 (3), 565-602, http://dx.doi.org/10.1093/ petrology/egq091.

White, S.M., Haymon, R.M., Fornari, D.J., Perfit, M.R., Macdonald, K.C., 2002 Correlation between volcanic and tectonic segmentation of fast-spreading ridges: evidence from volcanic structures and lava morphology on the East Pacific Rise, $9^{\circ}-10^{\circ}$ N. J. Geophys. Res. 107 (B8), 2173, http://dx.doi.org/10.1029/ 2001JB000571.

White, S.M., Mason, J.L., Macdonald, K.C., Perfit, M.R., Wanless, V.D., Klein, E.M., 2009. Significance of widespread low effusion rate eruptions over the past two million years for delivery of magma to the overlapping spreading centers at $9^{\circ} \mathrm{N}$ East Pacific Rise. Earth Planet. Sci. Lett. 280, 175-184.

Zaino, A., Klein, E., Wanless, D., Ridley, W.I., White, S., Perfit, M., Nunnery, A., 2008 Phenocryst abundances and compositions at the $9^{\circ} 03^{\prime} \mathrm{N}$ Overlapping Spreading Center: implications for magma source composition. Eos. Trans. AGU 89 (53), Fall Meet. Suppl., V41B-2085. 